\title{
O SIMBOLISMO ESSENCIAL DAS BRIGAS DE GALOS
}

\author{
Sérgio Alves Teixeira
}

Universidade Federal do Rio Grande do Sul - Brasil

\section{Introdução}

Embora as brigas ou rinhas de galos sejam reputadas por muitos investigadores acadêmicos e esportivos como a mais antiga modalidade de esporte do mundo e, contemporaneamente, sejam praticadas em numerosos países, em todos os continentes, com exceção evidente da Antártica, elas são pouco conhecidas fora dos seus círculos esotéricos (não sem razão, como se verá) e, quando este conhecimento se estende para além deles, como regra, é de modo fragmentário e distorcido. Em conformidade com tal desconhecimento, a abordagem do tema pelas artes e, mesmo, pelas ciências sociais, é modesta em relação à difusão de tal prática, intensidade com que é desenvolvida e emocionalidade que desperta.

O cinema ilustra bem esta questão. A comparação com a ampla filmografia, mais ou menos centrada nas práticas de esporte/lazer que estão mais próximas das brigas de galos, como touradas e lutas de boxe, por exemplo e por si só, comprova a pouca atenção que as artes dedicam às rinhas.

No cinema só sei de três filmes voltados para a questão: El gallo de oro (1964-México), com argumento de Juan Rulfo (1980), filmado por Roberto Gavaldón; Cockfighter ${ }^{1}$ (1974-Estados Unidos), dirigido por Monte Hellman, com argumento e roteiro de Charles Willeford e S'en fout la mort ${ }^{2}$ (1990-França), dirigido por Claire Denis. De modo extremamente sintético pode-se dizer que o primeiro aborda a questão do jogo nas rinhas e que o terceiro considera as visões divergentes de dois amigos sobre elas, um que não as

1 Referido por Dundes (1994a, p. 287).

2 O único a que tive a oportunidade de assistir. 
compreende e o outro que é aficionado por elas. Do segundo não disponho de mais informações. Certamente, que $S$ 'en fout la mort foi o que teve a melhor trajetória, sendo inclusive indicado para o prêmio de melhor direção no Cesar, o equivalente francês ao Oscar de Hollywood.

Na literatura, pintura e escultura a presença das rinhas já é um pouco mais expressiva. Danaë (1989) reproduz fotos de quadros e esculturas e Dundes (1994a, p. 243-245) arrola novelas, poesias e pinturas inspiradas no tema.

Na literatura, pela sua grande repercussão, com múltiplas edições e traduções, entendo oportuno referir o romance El coronel no tiene quien le escriba, de Gabriel García Márquez (1973), a novela Roots, de Alex Halley (1977), que forneceu argumento para uma série de televisão com o mesmo título, com larga distribuição internacional e a poesia “Galo de rinha”, de Jayme Caetano Braun (1979), poeta maior do tradicionalista gaúcho, ${ }^{3}$ amplamente difundida entre galistas brasileiros e tradicionalistas gaúchos. Como se verá adiante, esta poesia expressa com fidelidade a identificação de homens (gaúchos no caso) e galos, por exibirem atributos comuns, centrados em coisas como bravura e coragem, que também são exaltadas por aqueles tradicionalistas. Esta questão diz respeito a uma das maiores preocupações deste ensaio.

Contrastando com uma presença numérica pouco significativa nas artes, em termos estéticos e emocionais as brigas de galos aparecem com grande expressividade. Isto decorre da dramaticidade com que se revestem e das paixões que inspiram.

No campo das ciências sociais, os estudos sobre as brigas de galos, sempre em termos relativos, já têm uma maior presença. Com certeza, neste campo, não é por acaso que os estudos mais numerosos e aprofundados sobre o tema se situam na área da Antropologia, onde também se insere este ensaio. Afinal, ela sempre privilegiou a abordagem de temas não primeiramente associados à manutenção/conquista/ruptura do poder econômico/político e por isto considerados desinteressantes ou mesmo menores pelas demais ciências sociais. ${ }^{4}$

Mesmo que também na área das ciências sociais haja estudos marcadamente descritivos sobre o tema, o que por si só não lhes tira a importância,

\footnotetext{
3 Ver Teixeira (1988), Oliven (1992) e Maciel (1994).

4 A propósito de temas priorizados pelas diversas ciências sociais, ver DaMatta (1978b).
} 
meu interesse volta-se, sobretudo, para os estudos orientados para a interpretação das brigas de galos, percebidas como fato social relevante.

Dentre tais trabalhos, aparece como o mais notório Um jogo absorvente: notas sobre a briga de galos balinesa, de Clifford Geertz, publicado pela primeira vez em 1972. Pelo caráter altamente inovador e sedutor na abordagem do tema, que apresenta como "tese geral [...] que a briga de galos, e especialmente a briga de galos absorvente, é fundamentalmente uma dramatização das preocupações de status [...]” (Geertz, 1978, p. 304), tornou-se não só um marco nos estudos acadêmicos de tal prática, como também sobre representações em geral. Sua influência é tão acentuada, no que respeita especificamente aos estudos sobre as brigas de galos, que tornou-se referência quase obrigatória, ainda que sua análise reporte-se exclusivamente à sócio-cultura balinesa. Ele mostra todo este particularismo de seu ensaio ao dizer que

o que coloca a briga de galos à parte no curso ordinário da vida, que a ergue do reino dos assuntos práticos cotidianos e a cerca com uma aura de importância maior, não é, como poderia pensar a sociologia funcionalista, o fato de ela reforçar a discriminação do status [...], mas o fato de ela fornecer um comentário metassocial sobre todo o tema de distribuir os seres humanos em categorias hierárquicas fixas e depois organizar a maior parte da existência coletiva em torno dessa distribuição. Sua função, se assim podemos chamá-la, é interpretativa: é uma leitura balinesa da experiência balinesa, uma estória sobre eles que eles contam a si mesmos. (Geertz, 1978, p. 315-316).

Uma fácil comprovação da marcante influência de Geertz nos estudos acadêmicos sobre brigas de galos é fornecida por uma coletânea editada por Alan Dundes (1994b), com o título de The cockfight: a case book. Dos oito artigos posteriores ao estudo Geertz e publicados nesta coletânea, apenas um não se reporta a ele. O que não o exime de ásperas críticas, como as de Boon, Crapanzano, Jacobson, registradas por Dundes (1994a, p. 247) e Guggenheim (1994, p. 135-136), com ênfase na insuficiência de dados empíricos para sustentar suas interpretações, pensadas, assim, como marcadamente subjetivas.

Minha maior restrição ao trabalho de Geertz reside em seu particularismo. Voltado exclusivamente para uma manifestação particular de um fenômeno social de larga difusão, ele, simplesmente, é omisso em considerar o que tal fenômeno apresenta de essencial. 
Em oposição ao particularismo de Geertz, há muitos estudos voltados para uma interpretação mais geral ou mesmo generalizante para o sentido das rinhas de galos.

Entendo que o trabalho que melhor representa esta preocupação generalizante seja o ensaio de Dundes, ${ }^{5}$ cujo título se constitui em indicador preciso de sua orientação e abrangência: "Gallus as phallus: a psychoanalytic cross-cultural consideration of the cockfight as fowl play”, que encerra a coletânea por ele editada e já referida.

Logo na parte introdutória já mostra toda sua ambição ao dizer que apoiado em sólidas informações " [...] eu tentei encontrar uma estrutura simbólica que pudesse esclarecer a briga de galos não somente numa cultura particular, mas possivelmente em alguma extensão em todas as culturas em que a briga de galos existe” (Dundes, 1994a, p. 241, tradução minha). Isto porque ele percebe as brigas de galos como uma variação dos jogos/esportes em que os competidores expressam "sua virilidade, sua masculinidade, às expensas de um oponente masculino" (grifo dele). Neste caso, a "vitória acarreta [...] penetração”6 (Dundes, 1994a, p. 250, tradução minha). Com isto ele também está dizendo que tais jogos/esportes, possibilitam que, simbolicamente, desejos sexuais inconscientes sejam manifestados e concretizados.

Mais adiante apresenta sua hipótese: “a briga de galos é um duelo fálico masturbatório homoerótico simbólico mal dissimulado, com o vencedor emasculando o perdedor, através da castração ou feminilização” (Dundes, 1994a, p. 251, tradução minha).

Muito afim com tudo isto, apoiado em informações e considerações de autores diversos, Freud entre eles, percebe uma dimensão de sensualidade simbólica em práticas que integram o complexo das brigas de galos. Entre as práticas assim percebidas, incluem-se as apostas (Dundes, 1994a, p. 262-265) e o acariciar os galos com as mãos, o que é usual por parte de seus proprietários e auxiliares, como masturbação (Dundes, 1994a, p. 265-266) e a colocação da cabeça dos animais na boca dos tratadores, como parte de seus esforços para recuperá-los nos intervalos dos combates, como felação (Dundes, 1994a, p. 268).

\footnotetext{
5 Renomado antropólogo e folclorista da Universidade da Califórnia/Berkeley.

6 Exemplifica com o futebol americano, onde a equipe vencedora penetra mais vezes na zona final da equipe derrotada e a tourada, onde o touro é penetrado pela espada do matador ou este pelos chifres daquele.
} 
Bem avaliando a complexidade de sua hipótese, Dundes reconhece que por pressupor um elemento inconsciente (grifado por ele), a maioria dos aficionados não deverá aceitá-la (Dundes, 1994a, p. 241). Meus dados confirmam inteiramente sua suposição: todos os quinze aficionados ou galistas, para usar uma categoria nativa, a quem apresentei suas proposições (seis deles com formação universitária), acharam-na sem sentido.

Em relação ao artigo de Dundes meu ensaio apresenta uma convergência e uma divergência, ambas absolutas e fundamentais. A convergência diz respeito à preocupação ou, melhor dizendo, à crença, em uma estrutura simbólica, para usar suas palavras e simbolismo essencial, nas minhas palavras, inerentes às rinhas em si mesmas, que se manifesta onde quer que elas sejam realizadas. A divergência diz respeito exatamente ao que cada um de nós encontrou como constituindo a estrutura simbólica/simbolismo essencial das rinhas.

Em oposição ao fundamento inconsciente das rinhas, que traz à cena expressões simbólicas de sensualidade mal dissimuladas apresentadas por Dundes, apresento um fundamento fortemente ancorado no consciente e que põe em evidência certos atributos largamente pensados como definidores da masculinidade moral, celebrando-a. Refiro-me a brio, coragem, estoicismo, dignidade e coisas no gênero, que os aficionados também atribuem aos galos e que, por princípio, são sempre exibidas pelos homens verdadeiros em situações de adversidade e pelos galos em combate.

Minhas atenções iniciais para as brigas de galos se manifestaram em 1987, de forma até certo ponto periférica, vinculadas a meus interesses por rituais seculares e acusações de desvio social, situações emblematicamente representadas por elas. Com o passar do tempo, à medida que percebia sua riqueza simbólica e a paixão que despertavam em seus aficionados, mais e mais aumentava meu interesse por elas. Assim, muito naturalmente, resolvi abordar o tema em um estudo abrangente. Para tanto, a meu juízo, é imperativo que tal estudo também contemple uma análise estrutural comparativa entre o que entendo sejam os dois únicos tipos básicos de rinhas. O que os distingue é a probabilidade/previsibilidade de morte em combate ou o inverso. Para mim, esta abordagem adquire maior relevância pelo fato de desconhecer qualquer estudo que assim trate da questão.

Especificamente com relação às rinhas no Brasil, afora meus próprios trabalhos, só conheço, na área acadêmica, o de Leal (1989), de abrangência 
muito menor do que a deste ensaio. É interessante registrar que esta autora, diversas vezes citada por Dundes em apoio à sua tese do caráter fálico das brigas de galos conclua seu trabalho, como ele também assinala e lamenta (Dundes, 1994a, p. 273), com interpretação oposta, dizendo que: “a briga de galos é uma celebração da masculinidade onde os homens [...] reforçam certos atributos acreditados como essência do masculino" (Leal, 1994, p. 210, tradução minha).

Sem prejuízo de uma abrangente abordagem das rinhas como prática esportiva mundial, minha disposição de contribuir para o conhecimento do padrão brasileiro de rinhas, associada a facilidades operacionais, determinaram a ampla preponderância de dados brasileiros na etnografia.

As pesquisas de campo que forneceram o material para este ensaio foram realizadas, basicamente e com intermitência, no Brasil (1987, 1989, 1994 e 1996) e na França (1990/1991).

No Brasil, onde as pesquisas foram intensas, o trabalho de campo, nos três primeiros períodos, foi nucleado no principal rinhedeiro - espécie de ginásio esportivo próprio para brigas de galos - do Estado do Rio Grande do Sul e em uma das mais renomadas cocheiras ou coudelarias brasileiras - estabelecimentos dedicados à criação/treinamento de galos de brigas -, ambos localizados na cidade de Porto Alegre, com cerca de 1.500.000 habitantes. Neste Estado, que ocupa destacada posição no cenário galístico brasileiro, também se situa, na cidade de Ijuí, a maior cocheira do Brasil, e que fornece galos de briga para todo o país. ${ }^{7}$

O rinhedeiro, pertencente à Sociedade Avícola Bankiva, situa-se num bairro residencial/comercial, que pode ser caracterizado como de classe média média, próximo à área central da cidade. A cocheira junto à residência de seu proprietário, senhor João Veppo, empresário do setor de serviços, localiza-se num bairro tipicamente residencial, de classe média alta, afastado do centro da cidade. Trata-se de um dos mais renomados galistas brasileiros que desfruta também de reconhecimento internacional. Por sua atuação como galista de escol tem recebido a atenção de respeitadas revistas especializadas, como Canta Claro (1991, p. 11), editada no México.

Folha de S. Paulo, 15/03/1992, p. 4-2. 


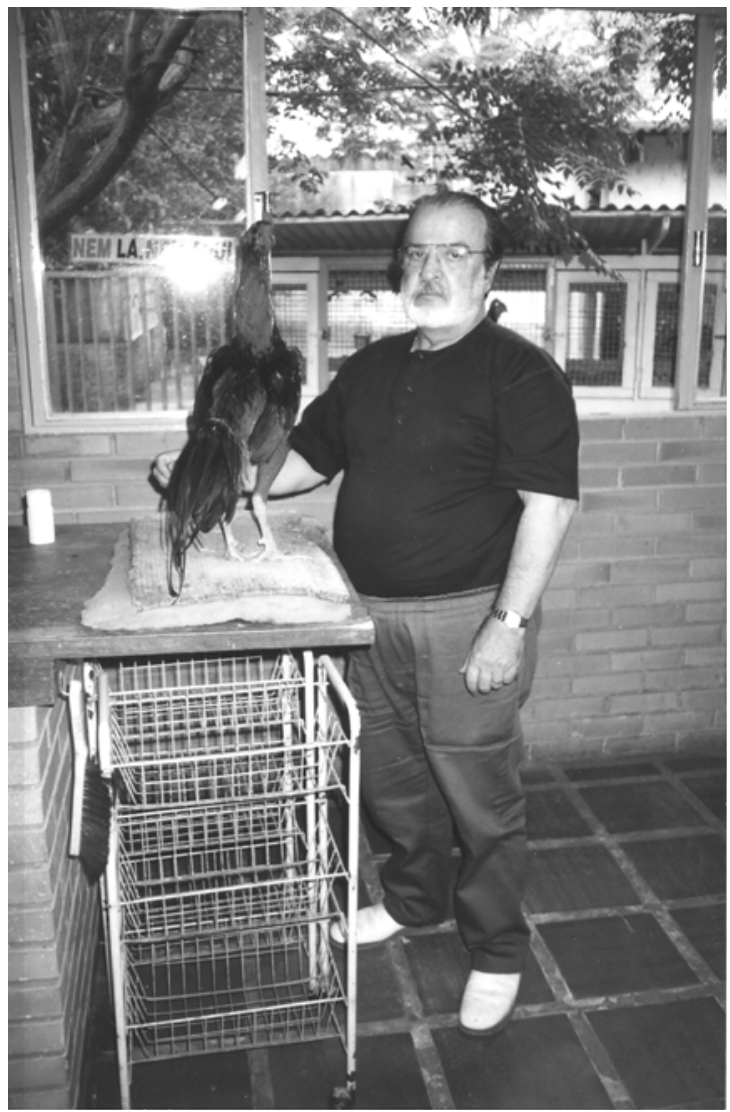

0 renomado galista João Veppo com um de seus galos.

As pesquisas nos dois estabelecimentos compreenderam observações sistemáticas e entrevistas, com pessoal técnico e aficionados, sendo que três destes eram de outros tantos Estados do Brasil. ${ }^{8}$

8 Foram realizadas nos três primeiros períodos 19 entrevistas, observadas 35 rinhas e numerosos e diversificados exercícios e treinamentos, bem como atendimento geral dispensados aos galos. Em 1989, quando de uma reunião acadêmica em San Juan, Porto Rico, também realizei cinco entrevistas: com dois galistas locais e com três pesquisadores, que também participavam do evento, com conhecimento do tema em seus países: Cuba, México e Argentina. 
O último período da investigação no Brasil foi dedicado, sobretudo, à consideração das apreciações de galistas a respeito de outros textos que escrevi sobre brigas de galos. O material, previamente por mim distribuído, foi discutido com quatro galistas que, no meu entendimento, poderiam contribuir para a compreensão do tema. Com eles também procurei complementar dados e esclarecer certas questões. Dos quatro galistas com que trabalhei neste período, dois eram de Porto Alegre e dois da cidade de Rio Pardo, também no Rio Grande do Sul, e centro galístico de larga tradição. Aí, também visitei seu principal rinhedeiro, assistindo a cinco combates.

A pesquisa na França, em 1990/1991, ${ }^{9}$ fez parte de meu plano de trabalho, em missão de estudo que lá realizei, como parte de um convênio de cooperação universitária entre este país e o Brasil.

A investigação de campo foi realizada em Paris e no Gallodrome (rinhedeiro) d'Annequin, na região de Pas-de-Calais, com uma visita. Aí fiz observações, assisti a onze combates e entrevistei dois galistas. Em Paris, além de investigações em bibliotecas e livrarias, cabe destacar uma longa entrevista com o advogado e expert em brigas de galos, Olivier Danaë (1989), autor do já referido Combats de coqs: histoire et actualité de l'oiseau guerrier. A investigação na França foi determinada pela necessidade de dispor de dados para uma análise comparativa, entre brigas com grande probabilidade/previsibilidade de morte em combate, como se dá aí, e o seu inverso, como no Brasil.

A reação dos galistas à pesquisa, desde o início cientificados de seu interesse estritamente acadêmico, foi sempre muito positiva. Entenderam-na como um tipo de reconhecimento da legitimidade e relevância das rinhas. Todas as entrevistas foram marcadamente abertas.

Quanto à sua estruturação, este ensaio se compõe de mais cinco partes. Como é de meu feitio, suas partes são suficientemente autônomas e completas, para permitir uma leitura isolada e inteligível de qualquer delas. Em seu conjunto, todo o trabalho foi estruturado e desenvolvido de modo a oferecer uma análise totalizadora e aprofundada de sua temática. Por isto e, também,

9 De fato, precisando bem as coisas, minha primeira incursão pelas brigas de galos na França ocorreu em 1987, quando assisti à defesa da tese de doutorado de Marie Cegarra: Le cercle, le plume, le sang: étude anthropologique des combats de coqs dans le Nord de la France, na École des Hautes Études en Sciences Sociales. Registro que causou-me espanto a dureza das críticas formuladas na ocasião, pela orientadora do trabalho, Françoise Zonabend. 
para evitar reiterações desnecessárias, entendo dispensável a apresentação de uma parte com conclusões.

As demais partes, com uma síntese de seus conteúdos, são:

Os dados - apresenta um conjunto bastante abrangente de informações básicas sobre as rinhas, de seu surgimento à atualidade.

A legitimidade - considera a questão da legitimidade social das rinhas e apresenta os argumentos dos que lhes são favoráveis e contrários.

O padrão brasileiro - coloca em cena os dados etnográficos a partir dos quais apresento o que pode ser pensado como sendo o padrão brasileiro das brigas de galos.

O jogo - aborda a questão, considerada como de importância fundamental, das apostas nas brigas de galos, enfatizando suas modalidades, interesses e significados.

O simbólico - analisa comparativamente, em múltiplos espaços sócio-culturais, os dois tipos básicos de rinhas, definidos pela probabilidade/previsibilidade ou não de morte em combate e concentra atenção no que entendo ser o seu significado essencial. Contribuir para a sua compreensão se constitui no objetivo maior deste estudo.

O trabalho é ilustrado com uma gravura e nove fotografias.

Encerrando esta parte, agradeço, não por ser de praxe, mas por ser devido, às pessoas a cuja boa vontade e compreensão, devo a concretização deste trabalho.

\section{Os dados}

Como é próprio às praticas esportivas institucionalizadas, as brigas de galos também são objeto de uma ampla literatura especializada. A par de considerações técnicas, voltadas em última análise, para os combates, como seleção genética, alimentação, saúde, treinamento, etc., dos galos, esta literatura também aborda questões não técnicas, porém julgadas relevantes pelos galistas, que é também, via de regra, a condição de seus autores. Tanto assim, que tais questões se repetem, com ênfase na história e na defesa da legitimidade das rinhas.

Dentre um grande número de tais obras destaco duas de autores brasileiros e duas de autores de outras nacionalidades, todas úteis para galistas e leigos no assunto. 
Campeões da arena, de Campello (1954) e Galos de briga e brigas de galos, de Elias (1978), representam os primeiros; El gallo de combate, de Vargas (1986) e o já mencionado Combats de coqs: histoire et actualité de l'oiseau guerrier, de Danaë (1989), representam os segundos. Por sua grande abrangência, impõe-se uma menção particular ao último.

Afora os elementos comuns aos livros especializados em brigas de galos, já referidos, o de Danaë também inclui um panorama das rinhas no mundo contemporâneo e uma pertinente análise de seu simbolismo. Ainda assim, ele é omisso em relação ao Brasil, onde, como se verá as rinhas têm grande expressão. Inquirido a respeito, por mim, quando de nossa entrevista, lamentou a omissão, atribuindo-a à não disponibilidade de estudos sobre elas. Por sua vez, isto confirma, como já disse, que é reduzido o número de tais estudos no Brasil.

Pela abrangência, que inclui também as respectivas bibliografias, o trabalho de Danaë e a coletânea editada por Dundes, respectivamente, pelo lado da literatura técnica e sociológica, são referências da maior valia para quem tiver interesse pelas brigas de galos.

Segundo entendimento geral expresso na literatura galística, as rinhas de galos se originaram no norte da Índia, em torno de 2.500 a.C., com a domesticação de galos selvagens, da espécie Bankiva, cujo nome científico é Gallus-Gallus, da qual derivam todas as raças de galos de briga (Campello, 1954, p. 17; Danaë, 1989, cap. 1, 2).

Em apoio à tese de que as rinhas se constituem numa das mais antigas práticas esportivas do mundo, Elias (1978, p. 13) diz que "no código de Manu, escrito aproximadamente há 5.000 anos [...] encontramos os primeiros rudimentos de regras, o que vem provar sua surpreendente longevidade”.

A difusão das brigas de galo pelo mundo inicia-se já na antigüidade, onde há registros arqueológicos que atestam sua presença no Egito, Mesopotâmia, Grécia, Roma (Danaë, 1989, cap. 3).

Considerando a situação contemporânea, ele registra (Danaë, 1989, p. 19) como centros galísticos de intensa atividade, a Polinésia; nas Américas: todos os países, exceto o Canadá; na Europa: Escócia, Flandres e Andaluzia; na África: Madagascar; na Ásia: China, Tailândia, Filipinas, Bali e Japão. Embora ele não inclua a Austrália entre tais centros, tenho seguras informações que autorizam a fazê-lo. 
Também me parece relevante registrar que as rinhas, hoje como no passado, têm nos centros urbanos seus loci preferenciais. Danaë (1989, cap. 2) associa os primórdios da domesticação e criação de galos de briga às sociedades urbanizadas do Punjab e do vale do Indo. Já de início comprometido com a defesa das rinhas, ele também proclama que

longe de ser um jogo bárbaro criado por homens rudes e cruéis, as brigas de galos se desenvolveram em um mundo pacífico de agricultores comerciantes que praticamente não deixaram nem um traço de atividades guerreiras, mas ao contrário, nos transmitiram numerosos testemunhos de um gosto extremamente desenvolvido para a arte, a decoração e a arquitetura. (Danaë, 1989, p. 38, tradução minha).

Tudo isto me permite afirmar que não corresponde à realidade dos fatos a vinculação das brigas de galos a nacionalidades, etnias e níveis de desenvolvimento urbano-industrial como pretendem alguns.

Ainda que dados estatísticos sobre as rinhas sejam escassos, alguns dos poucos de que disponho ajudarão a visualizar a magnitude de seus números. Na França há mais de 100 rinhedeiros, onde se realizam cerca de 40.000 combates anuais (Danaë, 1989, p. 215); dados da década de 70, mostram para os Estados Unidos, 70.000 criadores de galos de briga, 500.000 galistas, não menos de 250 rinhedeiros só na cidade de New York e algo como US\$ 10.000.000,00 anuais em negócios com rinhas (McCaghy; Neal, 1994, p. 68).

Mesmo com ausência de números, outras informações oferecidas por Danaë (1989, p. 187, tradução minha) permitem avaliar o imenso destaque alcançado pelas rinhas em certos países, como nas Filipinas, onde "não há uma cidade, um povoado ou uma vila que não possua um rinhedeiro”.

Sobre o Brasil não há, simplesmente, qualquer dado confiável. Vez por outra aparecem na imprensa matérias sobre rinhas, com apreciações, por princípio distorcidas e números, cujas fontes, não são informadas ou não inspiram confiança. Folha de S. Paulo fala em 50.000 criadores e 1.000.000 de aves, ${ }^{10}$

${ }^{10}$ Folha de S. Paulo, 15/03/1992, p. 4-2. 
já $O$ Estado de S. Paulo calcula "que existam cerca de 500.000 pessoas dedicadas ao 'esporte" " no Brasil. ${ }^{11}$ Meus próprios entrevistados quando consultados sobre a questão, se limitavam a expressar a idéia de que os números a respeito das rinhas devem "ser uma coisa de louco, de tão grandes" como disse um deles. Por não dispor de números, forneço indicadores que, acredito, contribuem para bem se avaliar a real expressão das rinhas no Brasil.

O fato de o país possuir mais de 5.000 municípios, a maioria dos quais com ao menos um rinhedeiro, sendo que muitos possuem até diversos deles, junto com outros dados a serem considerados na terceira parte deste ensaio, permite pensar que o número de galos, de galistas e de combates no Brasil, seja imenso.

As brigas de galos põem em confronto dois combatentes de raças com disposição natural para lutar sempre que se defrontem, criados e treinados para tal finalidade e equiparados em peso e armas. As armas são as esporas, na imensa maioria dos casos artificiais, com predominância das de aço ou de outro metal, colocadas por sobre os cotos das naturais ${ }^{12} \mathrm{e}$ fixadas às pernas por meio de esparadrapo ou cordões.

Embora de materiais diversos, como dentes de tubarão e de casco de tartaruga, predominam as de metal (aço, ferro, duralumínio, alpaca). Mostrando adaptação aos novos tempos, recentemente, por sua dureza e leveza é crescente o uso de fibra de carbono para confeccionar tais equipamentos. Mais raramente, usam-se esporas retiradas de outros galos e fixadas daquela mesma maneira. Os combates com esporas verdadeiramente naturais é mais raro ainda. O uso de esporas artificiais tem como fundamento maior a equiparação dos combatentes. Com esporas naturais tal igualdade é inviável. A equiparação em peso, como no boxe, visa a que as lutas se definam pela competência dos lutadores, acrescida no caso dos galos, pelo que é acreditado, ser sua coragem, brio, estoicismo, dignidade, que por sua vez são pensados como atributos morais inerentes aos homens de verdade. Muito afim com isto, as brigas de galos são quase uma exclusividade masculina.

Porque, independente das regras que disciplinem os combates, exceto pelas armas utilizadas, a intervenção humana não interfere em sua essência,

${ }^{11}$ O Estado de S. Paulo, 19/07/1995, G-15.

12 Serradas no início da preparação dos combatentes. 
é a natureza dos galos que define o desenvolvimento e resultados de seus confrontos. Assim, mundo a fora, as variações que as brigas de galos possam apresentar são mais de forma do que de conteúdo.

Ainda assim tais armas têm importância determinante na organização dos combates. É a partir delas, por seus tamanhos e formatos, que se configuram os dois tipos básicos de rinhas já indicados na introdução e definidos pela probabilidade/previsibilidade ou pela improbabilidade/impossibilidade de morte em combate.

O primeiro tipo é o mais difundido, sempre com combates programados para ter curta duração, entre 5 e 10 minutos, com a morte por vezes atingindo os dois combatentes. Já o segundo tipo, de difusão muito mais restrita, apresenta combates sempre programados para ter longa duração, entre 30 minutos e 1h30min, com a rara/pequena ocorrência de morte atingindo tão somente um dos combatentes.

O tempo programado para duração dos combates guarda uma lógica relação com o potencial de letalidade das armas utilizadas em cada caso. Combates com armas de alto potencial de letalidade tendem naturalmente a ter efetiva curta duração. Assim, na prática, seria sem sentido programá-los para longa duração. O inverso, portanto, se dá com os combates com armas com baixo ou nulo potencial de letalidade.

Tais tipos de combates, assim como se dá com a prática das rinhas em si, também não guardam relação necessária com nacionalidades, etnias ou níveis de desenvolvimento urbano-industrial. Tal afirmação encontra decidido suporte no fato do primeiro tipo de rinhas ser praticado em países como França, Filipinas ${ }^{13}$ (Guggenheim, 1994, p. 158; Danaë, 1989, p. 196) e Bali (Geertz, 1978, p. 288), enquanto o segundo tipo é praticado em países como o Brasil, Espanha $^{14}$ (Marvin, 1994, p. 176-177) e Tailândia ${ }^{15}$ (Danaë, 1989, p. 183). Já no México e Estados Unidos são praticados os dois tipos, de acordo com informações de entrevistados com conhecimento do que neles se passa.

${ }^{13}$ Uma particularidade dos combates filipinos é que sendo os galos geralmente "canhotos”, e as esporas aí usadas muito grandes, para evitar que os animais causem ferimentos a si próprios, só a perna esquerda é armada.

${ }^{14}$ Aí os galos lutam diretamente com suas esporas, para as quais também se busca equiparação.

${ }^{15}$ Danaë percebe as rinhas tailandesas como um combate de boxe, porque os galos combatem com suas esporas naturais envolvidas por tecido, de modo a que sofram/provoquem só ferimentos leves. 
As armas potencialmente muito letais são longas, com até mais de seis centímetros de comprimento, cortantes e/ou perfurantes como navalhas e lanças; as potencialmente pouco letais são mais curtas, pouco perfurantes e não cortantes.

As lutas se desenvolvem numa espécie de ringue, em regra circular, mas também quadrangular, sempre sob a condução de um juiz, cujas decisões são acatadas sem questionamentos. Mais do que ao fato das regras serem precisas e de todos conhecidas, tal se deve à respeitabilidade do juiz como galista e cidadão, critérios básicos para o desempenho da função.

Como no boxe, nas brigas de galos também há intervalos para repouso dos combatentes e cuidados de seus ferimentos. Geertz (1978, p. 289) destaca a crucial relevância do responsável por tais cuidados dizendo que como no

[...] boxe um bom treinador vale seu peso em ouro. Alguns podem fazer com que os mortos andem, praticamente, ou pelo menos o bastante para o segundo e último assalto... pois se o galo ainda pode andar, pode lutar, e se pode lutar pode matar, e o que conta é que galo que morre primeiro.

Quanto à extração social dos galistas, a literatura registra que em todos os lugares ela é bastante similar: compreende pessoas das mais diversas camadas sociais. No que respeita particularmente o caso brasileiro, acrescento a ausência de pessoas marcadas pela extrema pobreza (nas partes IV e V se perceberá o porquê disto), o amplo predomínio das camadas médias e faixa etária superior a 40 anos. A presença feminina nos rinhedeiros é muito rara e, quando acontece, se dá, sobretudo, na condição de acompanhante de um galista e é marcada pela discrição.

Thomas (1989, p. 172), registra o mesmo quadro nas rinhas da Inglaterra do século XVII, quando diz que "nelas se misturavam todas as camadas sociais, embora somente homens, pois neste esporte claramente não cabiam as mulheres”. A capacidade das rinhas de atrair adeptos de distintas condições sociais também pode ser reconhecida por quem as vêem com desprezo, como Dinwiddie (1994, p. 27-28, tradução minha), para quem, considerando-as em Porto Rico no século passado diz que "moralmente são mais repreensíveis do que as touradas”, para mais adiante acrescentar que camponeses pobres, ao lado dos "mais opulentos citadinos" apostam e "vociferam as virtudes de seus respectivos lutadores”. 
O interesse pelas rinhas despertado nos diferentes segmentos sociais, em si, não apresenta qualquer peculiaridade. Isto se dá, como regra, com todos os esportes. A peculiaridade está, isto sim, na proximidade em que se situam no interior do rinhedeiro e na possibilidade de interagirem em torno das coisas das rinhas.

Tomando o turfe e o futebol como contrapontos, eles também têm adeptos apaixonados em todos os segmentos sociais e que vão aos hipódromos e estádios. Porém, todos eles, ainda que irmanados pelos mesmos sentimentos despertados por tais esportes, vibram/sofrem, em espaços separados, que reproduzem grosso modo, a separação que vivenciam, fora deles, na sociedade abrangente, como integrantes de seus respectivos segmentos sociais.

Nos rinhedeiros, além de não haver tribunas, camarotes, cadeiras e locações populares, separando hierarquicamente o público como nos hipódromos e estádios, também pelo fato de ser raro um público superior a duzentas pessoas, todos podem se situar contíguos ou bem próximos do ringue.

Como foi dito na introdução não é sem motivo que as rinhas são pouco conhecidas. A razão, para usar a correta expressão de Danaë (1989, p. 233), é que seus adeptos formam "sociedades discretas". Em plena consonância com isto o artigo 16 dos estatutos da Sociedade Avícola Bankiva diz que serão excluídos os associados que "discutirem ou comentarem pela imprensa ou qualquer outro meio de divulgação, os atos da diretoria da sociedade, com os quais estejam em desacordo ou tornarem públicos atos da vida privada da sociedade”.

De fato, os galistas são avessos à publicidade externa das coisas das rinhas. Seus assuntos são tratados diretamente ou através de jornais/revistas especializadas, com circulação restrita aos aficionados. Não chamando a atenção da sociedade envolvente eles também preservam as rinhas de serem ainda mais atacadas. Suas comunidades são marcadas pelo paroquialismo, inclusive na incorporação de novos membros, sendo o parentesco uma importante via para tanto. Isto tem grande peso na formação da "verdadeira maçonaria galística”, de que falaram vários aficionados. Para mostrar que de fato ela existe, são pródigos em informações, como Seitenfus (1975, p. 40), quando afirma que sólidas amizades são proporcionadas por intermédio do esporte a seus aficionados. A experiência nos ensinou isto. Penso não existir agremiação alguma, nem civil, nem religiosa, em que seus participantes se dêem tão bem. 
Basta um cidadão ser cultor do esporte das brigas de galo para que, embora em cidade ou lugar desconhecido, receba honrarias dos esportistas do lugar. Une-os um propósito comum: o desenvolvimento do esporte. A mesma idéia de camaradagem é expressada de maneira sintética por um sentença escrita no interior do tambor em um rinhedeiro na cidade de Campos, no Estado do Rio de Janeiro: "enquanto os galos brigam os homens se [sic] confraternizam" (Elias, 1978, p. 129).

\section{A legitimidade}

Como a contestação da legitimidade social das rinhas praticamente as acompanham em todos os lugares onde elas existiram ou existem, entendo imperioso considerar a questão. Afinal, em que se baseiam os ataques e, conseqüentemente, também, a sua defesa?

$\mathrm{Na}$ atualidade seus críticos atacam-nas, sobretudo em nome dos sofrimentos que, dizem, são infligidos aos animais e, secundariamente, pelos efeitos negativos que sua prática pode trazer para a vida social. No passado, tais malefícios é que inspiravam os ataques às rinhas. A Inglaterra num passado mais distante e a Indonésia recentemente ilustram os ataques às rinhas inspirados neste último motivo.

Na Inglaterra, em 1365 o Rei Eduardo III proibiu as rinhas "para que o tempo livre fosse melhor usado na caça”; sob Cromwell e Carlos II, no século XVII, as proibições tiveram inspiração nitidamente política: os rinhedeiros reuniam pessoas potencialmente perigosas, que poderiam provocar até rebelião (McCaghy; Neal, 1994, p. 68). Contrastivamente, neste mesmo lugar e tempo, a prática das rinhas de galos também foi justificada pelas escolas inglesas “como um meio de incutir bravura nos estudantes” (Thomas, 1989, p. 219).

A ambigüidade e subjetividade envolvem a condenação das rinhas por sentimentos humanitários. Henry Alken, já em 1825, em seu livro The national sports of Great Britain, ${ }^{16}$ assinala que "escritores sensíveis condenam as

16 Trabalho mais antigo sobre rinhas a que tive acesso direto, publicado em francês e inglês, em Londres, sem indicação de editora. Disponível na Biblioteca Nacional, Paris. 
brigas de galos como prática cruel, enquanto outros, a defendem como prática legítima” (Alken, 1825, plate 39/40, tradução minha).

O mesmo Thomas (1989, p. 220) há pouco citado, avançando a discussão dos sentimentos humanitários em relação aos animais e, referindo-se à legislação inglesa dos séculos XVIII e XIX que criminalizava maus tratos a eles, diz que "no geral [...], a preocupação com o bem-estar animal fazia parte de um movimento mais amplo que envolvia a extensão de sentimentos humanitários a seres humanos anteriormente desprezados, como os criminosos, os insanos e os escravizados”. Isto, todavia, não o impede de reconhecer que cuidados e preocupações com os animais podem estar associados ao egoísmo, cinismo e auto-interesse de seus promotores.

$\mathrm{Na}$ Indonésia ou, mais particularmente em Bali, a proibição das rinhas foi associada ao projeto da elite nacional para a construção de um país moderno. Pela ótica de seu nacionalismo radical, as rinhas foram percebidas como primitivas, não progressistas e que transmitiriam uma imagem negativa do país no estrangeiro (Geertz, 1978, p. 280).

O jogo, que por definição, acompanha as brigas de galos também é invocado para combatê-las. As situações da Espanha, onde as rinhas são permitidas e do Brasil, onde elas não são proibidas, apresentam situações paradoxais, porque o jogo é proibido. Como o jogo integra o complexo das rinhas como um axioma, é impensável realizá-las sem ele. Daí que, para combater o jogo nas rinhas, será indispensável combatê-las também. Nos casos em apreço, nem uma nem outra proibição se concretiza. Marvin, aqui já referido, considera esta situação na Espanha. Embora não aprofunde a questão em seu excelente trabalho, tudo leva a crer que o fundamento para tal proibição seja o mesmo nos dois casos: proíbe-se o jogo de azar.

A conceituação de jogo de azar no Brasil, por si, mostra toda a complexidade que envolve a questão. Ela se dá no Artigo 50 da lei das contravenções penais, que proíbe os jogos de azar, e que em seu parágrafo terceiro diz que se consideram jogos de azar:

a) o jogo em que o ganho e a perda dependem exclusiva ou principalmente da sorte;

b) as apostas sobre corridas de cavalos fora de hipódromo ou de local onde sejam autorizadas;

c) as apostas sobre qualquer outra competição esportiva. 
Por tal conceituação é inegável que o apostar nas rinhas é uma modalidade de jogo de azar. Evidentemente que o item $b$, ao mostrar a força política do turfe, também sugere que muitas injunções devem ter pesado para a conceituação brasileira de jogo de azar.

Para efeito de comparação, sobre a noção de jogo de azar, trago à cena a importante contribuição de Caillois (1990, p. 32), destacando as duas primeiras das quatro categorias de sua classificação geral dos jogos: Agôn, Alea, Mimicry e Ilinx, considerando a predominância dos papéis de competição, sorte, simulacro ou vertigem, respectivamente.

Agôn compreende o conjunto "de jogos que aparece sob a forma de competição, ou seja, como um combate em que a igualdade de oportunidades é criada artificialmente, para que os adversários se defrontem em condições ideais, suscetíveis de dar valor preciso e incontestável ao triunfo do vencedor" (Caillois, 1990, p. 33-34, grifo meu).

Alea compreende "todos os jogos, baseados em clara oposição ao agôn, numa decisão que não depende do jogador, e na qual ele não poderia ter a menor das participações, e em que, conseqüentemente se trata mais de vencer o destino do que um adversário” (Caillois, 1990, p. 36-37). Sintetizando, diz que "o agôn reivindica a responsabilidade individual, a alea a demissão da vontade, uma entrega ao destino” (Caillois, 1990, p. 37).

Postulam os galistas que as rinhas remetem a agôn e não a alea, já que seus resultados decorrem da combinação da capacidade técnica/física dos galos com o brio, a coragem, o estoicismo, a dignidade com que se enfrentam.

No que respeita especificamente ao Brasil, ao contrário do que é freqüentemente acreditado, não há legislação específica, em nível nacional ou estadual que as proíba. Do mesmo modo também não há legislação em sentido oposto. Sendo assim a questão permanece em aberto, não obstante as muitas proposições para defini-la, nas esferas dos legislativos federal e estaduais. Já em nível municipal a situação se passa de modo distinto, com os jornais noticiando, vez por outra, que legislativos e executivos municipais, país afora, definem a questão, em ambas as direções, porém sem efeitos práticos, pois a questão não se situa na órbita da competência dos municípios. Por tratar-se de matéria penal, o assunto é da competência da União Federal.

Talvez porque as brigas de galos se situem entre as práticas sociais marcadas pela ambigüidade moral - que as tornam objeto de defesa e rejeição 
com a mobilização de intensa emocionalidade - a curta vigência da única proibição legal e geral das brigas de galos no país, há mais de 30 anos, por Decreto Presidencial, tenha provocado polêmica na época e ainda seja lembrada. Genericamente pode-se dizer que os galistas e seus simpatizantes discordaram de seu mérito; os neutros dizem que o Presidente da República deveria se preocupar com coisas mais relevantes; seus oponentes julgam-na ainda em vigor ou lamentam sua revogação.

A proibição se deu pelo Decreto n. 50.620, de 18/05/1961, do então Presidente Jânio Quadros e a revogação pelo Decreto n. 1.233, de 22/06/1962, do então Primeiro Ministro Tancredo Neves, também um aficionado pelas rinhas. Em reconhecimento os galistas lhe ofertaram um galo de ouro, cuja entrega foi feita pelo renomado galista de São Paulo, José Daniel Tosi, como mostra a fotografia ${ }^{17}$ a seguir.

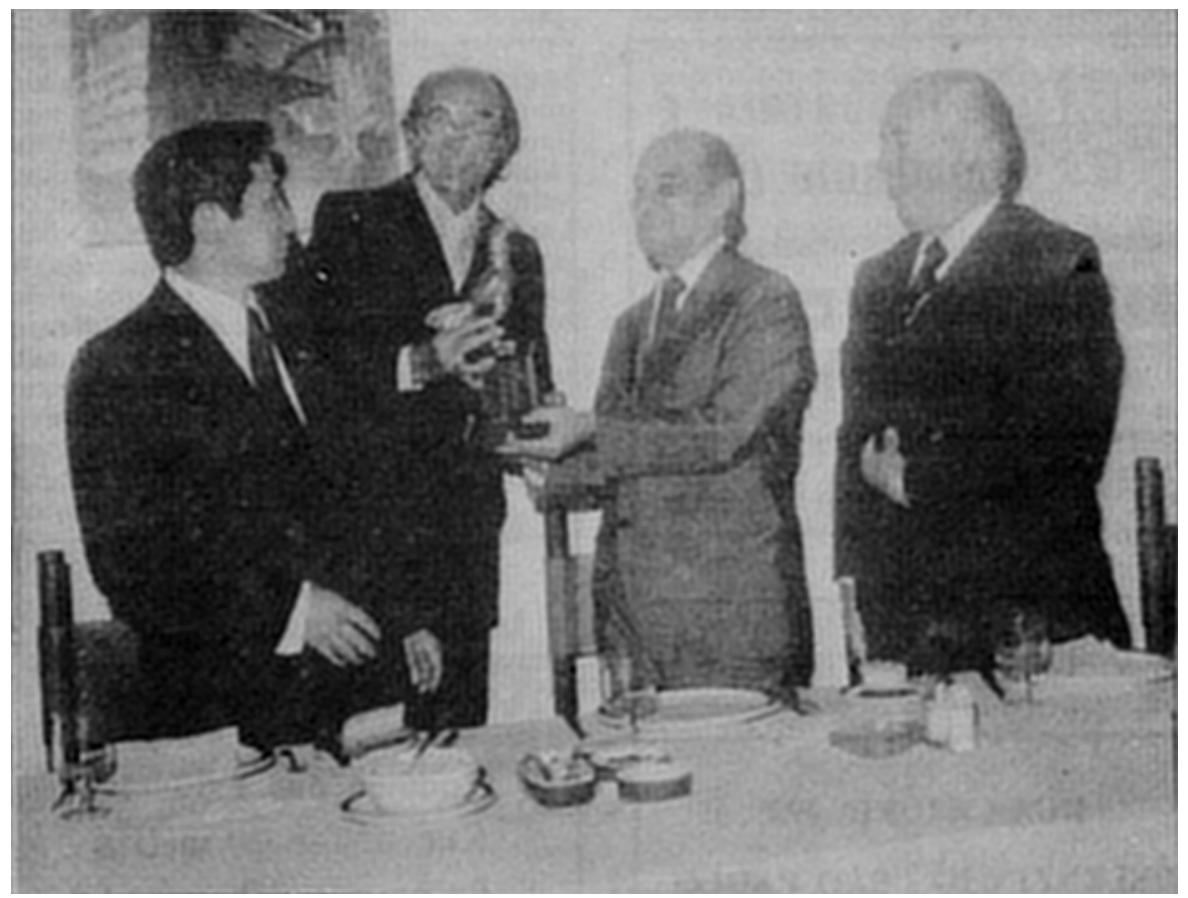

17 Reproduzida de Notícias da Rinha, n. 3, p. 3, 1986.

Horizontes Antropológicos, Porto Alegre, ano 3, n. 6, p. 223-280, out. 1997 
O Decreto que proibia as rinhas apresentava a seguinte exposição de motivos: "Considerando que todos os animais existentes no país são tutelados do Estado; que a lei proíbe maus tratos infligidos a quaisquer animais em lugar público ou privado; que as lutas entre animais estimuladas pelo homem constituem maus tratos; que os rinhedeiros converteram-se em locais públicos de apostas e jogos proibidos.” O Decreto, com quatro artigos, além de proibir de modo específico a organização de brigas de galos também proíbe genericamente a promoção de lutas entre quaisquer animais e diz que caberá às autoridades interditar os locais onde venham a se realizar e tomar medidas para a punição dos infratores.

Não obstante aquelas considerações a proibição das brigas de galos foi largamente interpretada, junto com outras proibições decretadas pelo Presidente, como estratégia para desviar a atenção pública de graves problemas enfrentados pelo governo. Incluem-se entre tais proibições a realização de corridas nos hipódromos em dias úteis, desfiles com biquínis, shows de strip-tease e de travestis. A renúncia do Presidente pouco depois (em 25/08/1961), permite pensar que tal interpretação não seja destituída de fundamento.

Com ou sem base legal, algumas ações mais concretas contra as rinhas e simples manifestações, sobretudo através da imprensa, se fazem sentir. Elas têm caráter episódico e localizado e se dizem voltadas para a proteção dos animais. Seus principais agentes são sociedades protetoras de animais e autoridades judiciárias e policiais. Em todo o país é no Estado de São Paulo que a ação do poder público é mais enfática contra as rinhas. Em decorrência, muitos galistas paulistas levam seus galos para lutarem no vizinho Estado de Minas Gerais. Ainda assim, o Estado de São Paulo, incluindo-se a aí sua capital, é um centro galístico de primeira grandeza. Afora a existência de diversos rinhedeiros em plena atividade, esta grande metrópole também abriga a exemplar coudelaria de um dos mais renomados galistas brasileiros, empresário industrial.

Deixando o caso particular do Brasil e voltando a tratar da legitimidade das rinhas em geral, registro que como é comum a grupos sujeitos a contestações, os galistas desenvolveram uma bem fundamentada racionália, em defesa da legitimidade social das rinhas. Em todos os lugares, seus dois primeiros argumentos se apresentam como faces de uma mesma moeda. Um é desqualificar o acusador/acusação; outro é afirmar que os galos se enfrentam 
naturalmente, por instinto, sem estímulos externos, sempre que se defrontam, para levar o adversário à morte.

A desqualificação, por princípio tentada em qualquer processo de defesa, inclusive na esfera do judiciário, no caso das rinhas concentra-se na hipocrisia do acusador/acusação.

A questão é bem posta nas considerações de Jean Cau, jornalista francês e membro de uma sociedade de proteção aos animais, que sintetiza a questão, quando diz:

Como se ousa fazer os galos lutarem entre si? Resposta: por se amar no mais elevado grau o que neles é o mais digno de ser amado e liberado; sua beleza, sua coragem e seu instinto. Ninguém mais do que um galista ama seus galos. São os galos-de-briga, animais nobres, livres, belos e orgulhosos, nos quais não se injetam hormônios e não se castiga os olhos; animais a que não se impede de dormir com poderosas lâmpadas; que não se aglutinam aos milhares, asa a asa nas granjas para que engordem em algumas semanas, onde vacilam miseravelmente sobre suas pernas de ossos frágeis; que não se mata, que não se fere e que não se embrulha em série em papel celofane. São, ao contrário, animais dos quais se cultiva a beleza, a força e a resistência física, aos quais se oferece a alegria, sim, a alegria de fazer-lhes explodir o que eles mais gostam no mundo: seu prodigioso instinto de combate, transmitido de geração a geração. (cf. Elias, 1978, p. 36).

Como é inata a disposição dos galos para a luta sempre que se defrontem - o que é inquestionável - tal fato se constitui no principal argumento dos galistas em defesa da legitimidade das rinhas.

De tal modo esta disposição inata é, para qualquer galista, "o argumento" em defesa da legitimidade das rinhas, que ela se apresenta para todos os aficionados como razão suficiente para justificar sua prática. Mais ainda, nesta perspectiva, desumano seria não permitir que os galos lutassem, por contrariar sua natureza. Esta concepção, de modo mais ou menos consciente, se faz presente na mentalidade de todo o galista. Muitos dos galistas que entrevistei deixaram transparecer esta concepção, sendo que cinco a explicitaram plenamente.

A ênfase no argumento da disposição inata também se faz buscando apoio em outras áreas do pensamento, como Elias (1978, p. 35), citando a Súmula Teológica de São Tomás de Aquino, quando diz que "ninguém peca por usar uma coisa para o fim para a qual ela é destinada [...] Por isso não é ilícito usarmos [...] a utilidade dos animais para a nossa”. Assim ele conclui 
que é legítimo utilizar o galo combatente para atender às necessidades de esporte e divertimento do homem.

De tal modo, sendo as rinhas percebidas como um esporte, nada mais natural do que também buscar legitimá-las juridicamente. É o que faz Seitenfus (1975, p. 50), citando parecer de Nelson Hungria, quando Ministro do Supremo Tribunal Federal, em que diz

se é guardada a técnica do jogo a impunidade do vencedor tem que ser reconhecida ainda quando, desgraçadamente, resulte ao vencido alguma lesão grave ou mesmo a morte [...] A ilicitude do ato é essencial para que se possa imputar ao agente, a título de dolo, o resultado maléfico. Ora, a violência esportiva, em si mesma, não é ato ilícito, mas permitido.

Ainda assim, pelos ferimentos que os galos em combate se infligem, os galistas são acusados de atentarem contra a natureza. Ao que eles respondem exatamente em sentido oposto: reputam para si a condição de preservacionistas. Preservam os galos de briga da extinção e aperfeiçoam suas qualidades inatas.

Com integral razão alegam que, se não houver rinhas, as raças de galos combatentes deixarão de ser criadas e, portanto, correm sérios riscos de extinção; continuariam a ser preteridas por outras mais aptas para a produção de carne e ovos. No que respeita ao aperfeiçoamento de suas qualidades inatas a alegação também procede, é simplesmente uma questão de seleção genética.

As acusações de barbárie e crueldade também recebem contestações diretas.

Finsterbusch, já em 1929 (apud McCaghy; Neal, 1994, p. 73), sintetiza bem a questão ao dizer que

estigmatizar as brigas de galos como um esporte cruel e barbárico é um absurdo, quando nós sabemos que o homem mata milhões de seres vivos diariamente para saciar sua fome. A briga de galos não é senão um esporte natural organizado, do qual os espectadores tiram proveito para temperar seus nervos para a luta diária..., é talvez o único esporte onde uma decisão atende a mais perfeita honestidade.

A contestação dos galistas à natureza espúria imputada às rinhas, pela brutalidade que nelas vêem seus acusadores, também se dá com um mesmo 
tipo de argumentação que integra a racionália de aficionados por outras práticas que sofrem acusação análoga. Refiro-me à validação de uma dada prática pela notoriedade de seus praticantes, operacionalizando o antigo provérbio que sentencia: “diz-me com quem andas que dir-te-ei quem és”. Este é, por exemplo, o caso das touradas, que cito por estarem bem próximas das rinhas. Sobre elas Amorós (1988, p. 133, tradução minha), questiona “como pode ser inculta uma festa que interessou a James Joyce e Eisenstein, a Octávio Paz, a Dalí e Miró? Como pode ser sintoma de barbárie a festa que apaixonou Goya e Picasso, García Lorca, Hemingway e Orson Welles?”

No que tange às rinhas, Elias (1978, p. 25) diz que

é absurda e injustificável, pois, a atitude de certas pessoas contra as rinhas. No entender dessa gente, somente indivíduos de instintos baixos, sem qualquer qualificação dedicam-se à prática do esporte. Que mais errado pode existir?... Se déssemos ouvidos a tamanhas baboseiras, teríamos como marginais, além de muitos outros monarcas, Jayme I, Carlos II, Henrique VIII... Washington, Jefferson, Jackson e Lincoln... Benjamin... Hemingway...

Tais personalidades, citadas em muitas outras obras, que também costumam incluir outros galistas ilustres, como Alexandre Magno, Aníbal, César, Napoleão, com freqüência também são referidas em conversas com galistas.

Tudo isto não impede que o mesmo Elias (1978, p. 38) também argumente a favor das rinhas pelo seu caráter democrático, o que faz citando Machado de Assis que "definiu 'o galo de briga como o cavalo de corridas do pobre'”.

Em conformidade com tudo isto, McCaghy e Neal (1994, p. 73) mostram que vai de “Genghis Khan a Helen Keller” o espectro de celebridades aficionadas pelas rinhas, arroladas pelos seus defensores.

O esporte galístico, apesar de contestado em todo mundo, sendo inclusive proibido em diversos lugares, como na maioria dos Estados dos Estados Unidos e na Inglaterra, mostra grande vitalidade como já vimos, e tem conseguido algumas vitórias legais importantes. Entre elas estão os casos da França, onde desde 1964 as brigas de galos são legalmente autorizadas "nas localidades onde elas têm ininterrupta tradição” (Danaë, 1989, p. 216, tradução minha); do Brasil, onde a Federação Esportiva e de Preservação do Galo Combatente do Estado do Rio de Janeiro, por Lei Estadual de 1984, foi reconhecida como 
entidade de utilidade pública; ${ }^{18}$ na Argentina, em 1990, onde, na província de Tucumán, as rinhas foram legalizadas. ${ }^{19} \mathrm{Em}$ Cuba, onde foram proibidas pela Revolução Socialista e, com a reconsideração das autoridades, ganharam novo impulso, inclusive com apoio governamental. ${ }^{20}$ Lembro, há coisa de 7 anos, de um folheto de promoção turística, em que era registrado que Cuba era um importante exportador de galos de brigas.

No final de 1995 os galistas do Rio Grande do Sul vivenciaram uma situação de grande tensão, a que se seguiu uma importante vitória. Ambas as situações provocadas por uma lei aprovada pela Assembléia Legislativa, proibindo as rinhas e que teve o veto do Governador do Estado, por inconstitucionalidade, acolhido. Certamente que a mobilização da considerável força política dos galistas contribuiu para este resultado. Aliás, em todo o lugar, é esta força, aliada à paixão dos galistas pelas rinhas, que tem assegurado sua perenidade.

\section{0 padrão brasileiro}

Embora os galos possam ser levados a se enfrentar de modo mais ou menos improvisado em áreas ao ar livre, como em pátios, ou cobertas, como em galpões, as brigas ou rinhas bem organizadas, que são de longe as que predominam, as mais importantes e as que interessam a este trabalho, realizam-se nos rinhedeiros. Nos bem equipados, costuma haver serviços de bar e restaurante, sanitários e, logicamente, uma completa infra-estrutura voltada para as lutas propriamente ditas. Integram-na: gaiolas para alojar os galos levados para lutarem, balanças para pesá-los, mesas, pias, esporas e outros itens básicos para preparo e/ou cuidados dos galos que efetivamente chegam a combater; um tambor e, nos maiores, também, de um a quatro rebolos, isto é, arenas onde se enfrentam; cadeiras e/ou arquibancadas em torno de cada uma das arenas, para os galistas assistirem às lutas. Em rinhedeiros maiores, pode

${ }^{18}$ Calendário Galístico - 1984 - da mesma Federação, contracapa.

19 Informação de um galista desta província.

${ }^{20}$ Em 1993, um galista e integrante da alta administração do Estado do Rio Grande do Sul, durante missão oficial em Cuba, tentou, sem sucesso, adquirir um galo. Depois, já a bordo do avião em que retornaria, recebeu, pelas mãos de um militar, uma gaiola com duas galinhas e um galo de rinha, acompanhada da informação de tratar-se de um presente do presidente Fidel Castro. Episódio narrado pelo próprio galista. 
haver até dois mezaninos, superpostos, equipados com cadeiras. Também contam com um bom sistema de iluminação elétrica para manter as arenas bem iluminadas durante os combates.

O tambor consiste em uma área circular, com cerca de três metros de diâmetro, delimitada por uma parede de alvenaria ou de madeira, com aproximadamente $60 \mathrm{~cm}$ de altura, com estofamento interno revestido por material impermeável (para facilitar sua limpeza) e com piso de serragem ou atapetado. O rebolo é igual, com a única diferença de ser menor, com cerca de dois metros de diâmetro.

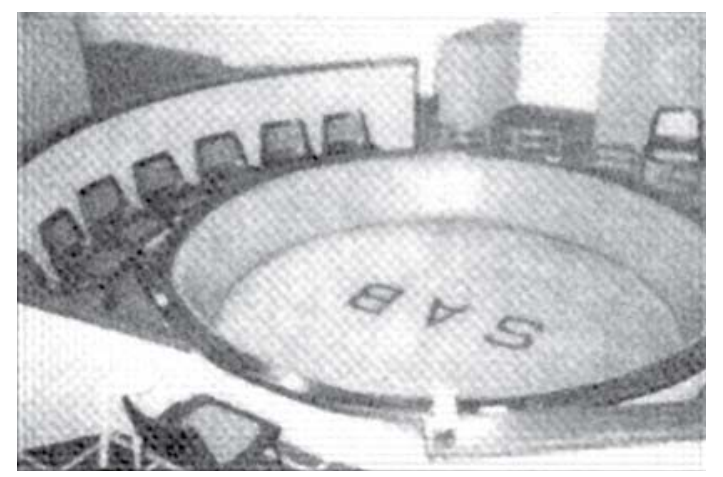

Tambor do rinhedeiro da sociedade Bankiva (foto: Noticias da Rinha, p. 9).

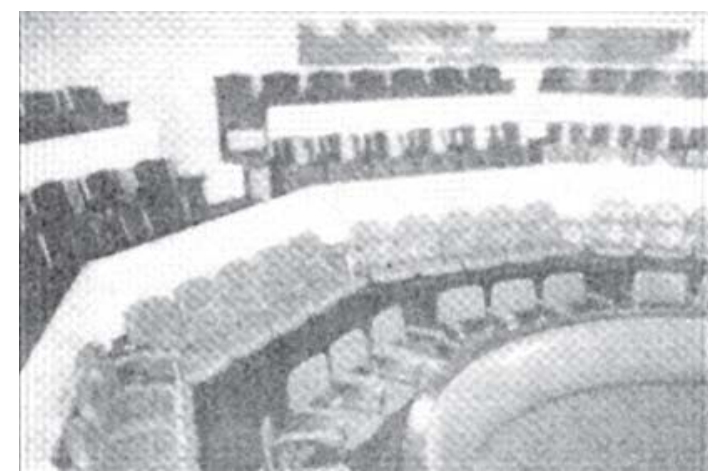

Vista parcial das arquibancadas da sociedade Bankiva (foto: Noticias da Rinha, p. 9). 
Dificilmente o centro do tambor dista mais de 10 metros de qualquer assento nas arquibancadas em torno dele ou dos mezaninos. Tal distância é sempre inferior no caso de qualquer dos rebolos, em relação aos assentos em torno deles. É usual que das cadeiras em torno das arenas, três estejam permanentemente reservadas: uma para o juiz e, ladeando a deste, uma para cada um dos proprietários dos galos em combate, ou seus representantes. Com freqüência os proprietários não ocupam as cadeiras que lhes são reservadas, preferindo assistir às lutas de outros locais para ficar junto às suas parcerias. Acrescente-se que muitos galistas, como associados do rinhedeiro, possuem cadeiras cativas, em geral em torno do tambor, identificadas por seus nomes.

Não só a grande maioria dos rinhedeiros se situa em centros urbanos como estão presentes na maior parte deles, incluindo-se as principais cidades, entre elas todas as capitais estaduais e a Capital Federal. O Clube Privé 5 Estrelas, considerado o principal rinhedeiro do país, pelo requinte de suas instalações e o elevado status social de seus freqüentadores, situa-se na Barra da Tijuca, bairro de classe alta, na cidade do Rio de Janeiro, e inaugurado em 1986. Outro rinhedeiro considerado de luxo é o de Manaus, o Centro Esportivo Nicolau Akel, inaugurado em 1991.

Rinhedeiros considerados modelares também podem estar presentes em cidades menores, como em Petrópolis, no Rio de Janeiro e em Juiz de Fora, em Minas Gerais.

Isto autoriza a que se possa empregar, com integral propriedade, a expressão consagrada do Oiapoque ao Chuí, ${ }^{21}$ para dar a devida ênfase à difusão das brigas de galos por todo o país.

De modo geral pode-se dizer que os rinhedeiros menores pertencem a particulares e que os maiores pertencem a sociedades galísticas, em muitos casos com personalidade jurídica. Os recursos regulares para sua manutenção provêm da venda de ingressos, com custo equivalente ao dos cinemas; de percentuais, de não mais de $10 \%$, sobre o valor das apostas ou paradas, estabelecidas para cada rinha; da exploração dos serviços de bar e restaurante e, naqueles pertencentes a sociedades galísticas, também de contribuições dos associados.

Embora haja um grande intercâmbio entre galistas, suas associações, incluindo aquelas com personalidade jurídica, têm atuação autônoma. Na

${ }^{21}$ Rios que assinalam os limites extremos das fronteiras norte e sul do Brasil. 
prática, só atuam de modo coordenado na organização de torneios e concentrações, com a participação de galistas de distintos lugares. Tais eventos compreendem desde aqueles que reúnem galistas de poucos municípios vizinhos, passando pelos regionais até os nacionais, envolvendo competidores da quase totalidade dos Estados do país. Os últimos são coordenados e regulamentados pela Coordenadoria Galística do Brasil e se realizam em capitais estaduais, em sistema anual de rodízio.

Esta Coordenadoria, como sugere seu nome, tão somente estabelece alguma coordenação nas atividades galísticas, sendo a principal a relativa aos torneios e concentrações nacionais. Mais do que uma sede ela possui uma liderança temporária, representada pelo coordenador, com mandato de dois anos.

Nos torneios, um número pré-determinado de galos compõem equipes, que representam, em geral, localidades distintas. Como regra, as equipes são integradas por galos de diversas parcerias. Neles há contagem de pontos, cuja pontuação é inversamente proporcional ao tempo que um galo leva para vencer seu combate. Nas concentrações, as mais usuais, os confrontos se dão entre galos que representam os galistas individualmente.

Nos rinhedeiros em que há mais de uma arena e, dependendo do número de lutas a serem realizadas, elas que sempre começam no tambor, a partir do terceiro round (cada um com duração de 15 ou 20 minutos) se desenvolvem em qualquer rebolo disponível, para que outros combates se iniciem. Certamente, não mais de $30 \%$ das lutas se encerram até o segundo round. É possível, num rinhedeiro com quatro arenas (que são poucos), o desenvolvimento de até três combates simultâneos e que num com três arenas possam ocorrer cerca de vinte e cinco confrontos num dia.

A temporada de rinhas se estende de maio/junho a dezembro/janeiro, período em que os galos não estão em mudança de penas. Os sábados e os domingos são os dias mais utilizados para realizá-las, com extensão para as quintas e sextas-feiras, por ocasião de grandes torneios ou concentrações de cunho regional ou mesmo nacional. Tais eventos ocorrem simultaneamente em numerosos lugares. Nestas oportunidades é freqüente a realização de mais de cem combates, num só local. Em dias de intenso movimento um rinhedeiro pode funcionar da manhã à noite.

O tipo de lutas organizadas no Brasil, programadas para ter longa duração e, portanto, sem a utilização de armas acentuadamente letais, mas que possibilitam que os adversários se inflijam duríssimos golpes pressupõe, como 
condição necessária para se desenvolverem, que os lutadores tenham condições físicas e atléticas para enfrentá-las. Para tanto, a intervenção humana é indispensável, o que se dá através de diversos procedimentos. Todavia, antes de abordá-los, é relevante considerar certas questões intrinsecamente associadas à natureza mais ou menos letal das armas.

No Brasil as esporas são basicamente cônicas ou cilíndricas, com até dois centímetros de comprimento (excluída a telha, base que serve para ajustá-las às pernas dos combatentes), com pontas que vão de bem finas até quase rombudas e cujo uso tem distribuição geográfica bem definida. As cônicas, que compõem o tipo chamado de arma gaúcha, predominam amplamente nos Estados do Rio Grande do Sul (onde se originaram), e de Santa Catarina. Já as cilíndricas, que compõem o tipo chamado de arma nacional, são utilizadas com quase exclusividade no resto do país, com exceção do Estado do Paraná, que estabelecendo uma espécie de divisor, utiliza os dois tipos de maneira bastante equilibrada.

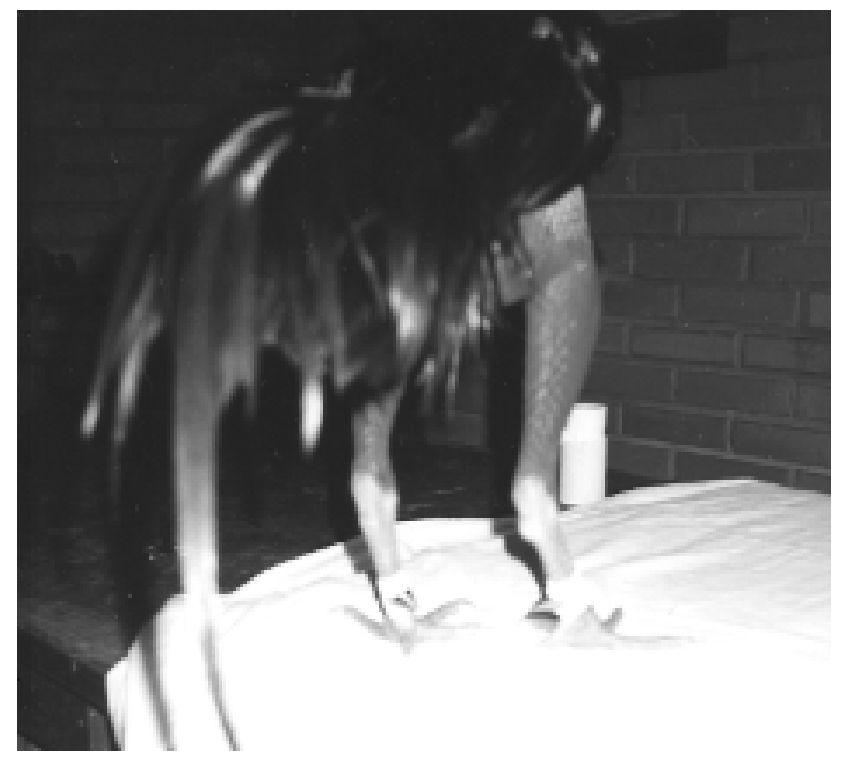

Galo com arma gaúcha

É oportuno registrar que uso experimental de uma arma híbrida, de nacional e gaúcha, não teve sucesso e que, há coisa de dez anos, na Região 
Norte do país, também esta em uso, porém em escala reduzida e para certo tipo de galos, um novo tipo de arma, em forma de cone alongado, inspirado em modelos do Caribe, e com potencial de letalidade superior ao da arma nacional. Não tenho condições de avaliar de até onde tal fato indica uma tendência de aumento generalizado de potencial de letalidade das armas utilizadas no Brasil.

Quanto ao potencial de letalidade, o das armas gaúchas é tão reduzido, que a ocorrência de morte em combate ${ }^{22}$ é considerada acidental, como se dá no boxe. Já o potencial de letalidade das armas nacionais, em relação ao daquelas é elevado, com a ocorrência de morte em cerca de 30\% dos combates.

O reduzido ou moderado potencial de letalidade das armas utilizadas no Brasil concorre, a um só tempo, para que a maior parte das lutas se aproximem do tempo programado para sua duração ou mesmo o atinjam, como também para que a maioria dos galos possa lutar muitas vezes ao longo de uma vida útil de até cinco anos.

O tempo de recuperação dos galos pelos ferimentos em luta, mesmo nos casos mais graves, não é superior a três meses. Assim é possível que alguns possam lutar até três vezes por temporada.

Para bem se avaliar a questão faz-se necessário uma comparação com as lutas organizadas com o emprego de esporas letais. Nestas não só raramente é atingido o curto tempo de duração programado, como a grande maioria dos galos dificilmente ultrapassa três lutas, no espaço de uma vida bem curta, com freqüência encerrada já no primeiro combate. Na França, conforme Cegarra (1988, p. 58) as mortes em combate se situam na faixa dos 60-70\%. Meus próprios dados apresentam números muito aproximados: das onze lutas a que assisti aí, todas programadas para cinco minutos, nenhuma ultrapassou a marca dos três minutos, com sete mortes, sendo que em uma morreram os dois lutadores. Aliás, de modo bastante aproximado com o que deve se passar em estado de natureza pois, por princípio, uma luta em tal situação não termina até que um adversário seja liquidado. As esporas naturais também podem ser letais.

As duas fotografias a seguir mostram diversos tipos de armas, usadas em diferentes lugares, com as da primeira em tamanho natural. As fotos foram feitas por Luiz Eduardo Achutti.

22 Apresentada a questão a cinco galistas, todos com mais de vinte anos de vivência em rinhas, lembraram um total de seis mortes em combate. 


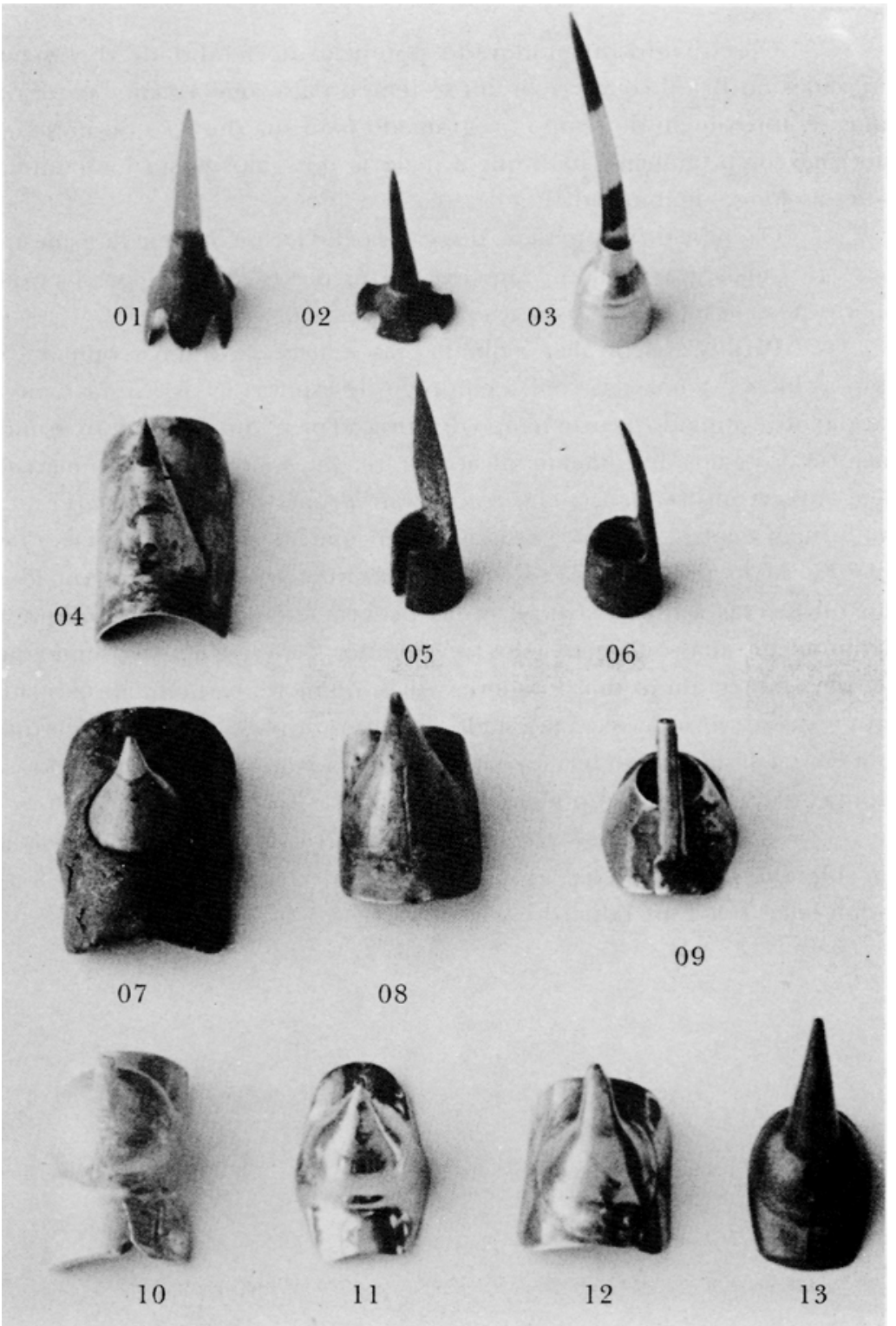

Armas utilizadas em diferentes lugares: Caribe: 1, 2 e 3; Uruguai: 4; Sumatra: 5 e 6; Argentina: 7; Colômbia: 8; Estados Unidos: 9; Brasil: 10 (arma nacional), 11 (arma gaúcha), 12 (híbrida da nacional e gaúcha), 13 (inspirada em modelos do (aribe) (foto: Luiz Eduardo Achutti). 


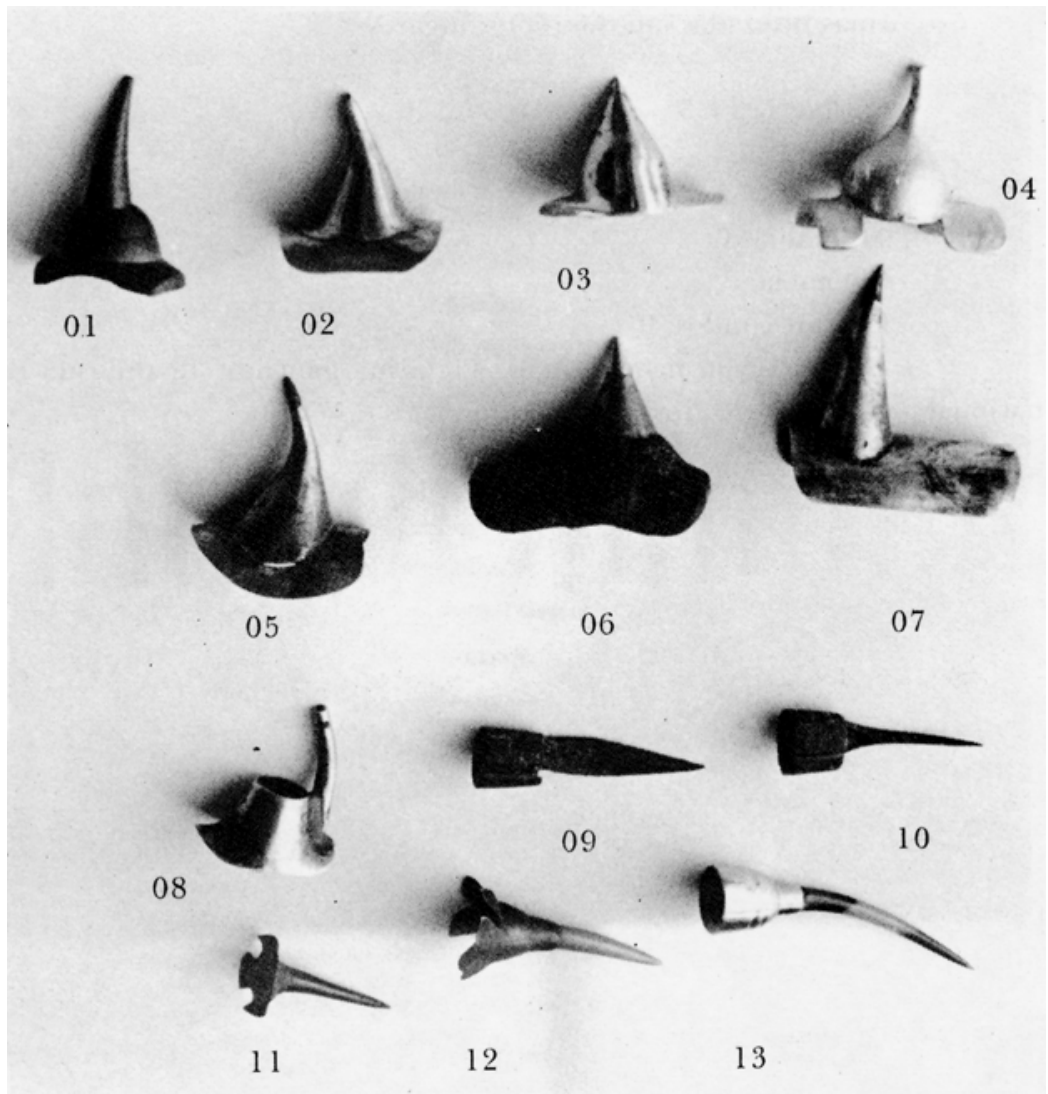

Armas utilizadas em diferentes lugares: Brasil: 1 (inspirada em modelos do Caribe), 2 (híbrida de arma gaúcha e nacional), 3 (arma gaúcha), 4 (arma nacional); Colômbia: 5; Argentina: 6; Uruguai: 7; Estados Unidos: 8; Sumatra: 9 e 10; Caribe: 11, 12 e 13 (foto: Luiz Eduardo Achutti).

Retorno agora à intervenção humana, em complementação ao uso de esporas não letais, para que lutadores possam enfrentar confrontos programados para ter longa duração, todas visando a que os galos mantenham condições de combate pelo máximo de tempo.

Um recurso da maior valia para a concretização deste objetivo é o uso de bicos de aço, cobrindo os naturais, para protegê-los durante as lutas. Trata-se de delicadas próteses, fixadas por meio de finos fios de linha. É uma inovação 
da década de 60, desenvolvida por um galista da cidade de Soledade, no Rio Grande do Sul. Os bicos, mesmo de aço, não são considerados armas, mas fundamentais para elas sejam eficazmente empregadas. Prendendo-se ao corpo dos adversários com o bico, os lutadores podem desferir golpes mais precisos e potentes do que os lançados sem este apoio. Com o uso desta prótese preserva-se tanto um importante elemento de combate, de difícil regeneração, como um elemento de igualdade entre os lutadores. Sem esta proteção era comum a perda de bico em combate, sobretudo do bico superior. Com a perda de condições de combate a luta pode ser suspensa. Este equipamento além de desnecessário nas lutas de curta duração, também é praticamente desconhecido onde elas imperam. Inclusive Danaë, que além de não mencioná-los em seu excelente trabalho tantas vezes aqui citado, me declarou desconhecê-los até o momento de nosso encontro.

Porque é sabido que a inclinação dos galos para a luta é inquestionavelmente de ordem natural, a seleção genética, voltada para a busca de melhores combatentes, é uma constante no universo galístico, com rigor científico. Nas criações mais avançadas a informática integra o processo.

Como também é sabido que esta disposição natural, por si só, não produz os melhores combatentes, aqueles que são selecionados pelas aptidões que desde cedo demonstram, são preparados e treinados para aprimorá-las.

A partir dos seis/oito meses de idade, ${ }^{23}$ quando os futuros combatentes são escolhidos, ${ }^{24}$ dentre um plantel de idade aproximada, inicia-se a fase propriamente dita de preparo e treinamento, que prossegue até o final de suas carreiras. A seleção se dá basicamente a partir de lutas-treino, com batoques ou buchas em lugar de armas, e com o uso de biqueira de borracha, para não se ferirem. Ainda que haja um considerável de galos, como a maioria dos galistas mantém criação própria, o processo de seleção e preparo inicial dos animais é de conhecimento e prática geral.

Nas cocheiras todos os galos são alojados individualmente em gaiolas fixas ou cercados móveis, sendo estes chamados de passeadores. À noite, nos dias chuvosos ou muito frios e úmidos, são alojados nas gaiolas; nos outros períodos, em geral, permanecem nos passeadores. Tais cercados, usualmente

${ }^{23}$ A partir dos três/quatro meses, quando já começam a brigar, os machos são separados.

${ }^{24}$ Os não selecionados são comidos, doados, vendidos ou simplesmente eliminados. 
feitos com sarrafos de madeira, tela de arame ou barras de metal, são retangulares, com cerca de $3 \mathrm{~m}^{2}$, com aproximadamente 1 metro de altura, e sem fundo, para que os galos possam ficar em contato direto com a terra. Enquanto as gaiolas são colocadas lado a lado, contíguas e sobrepostas umas às outras, em espaços cobertos, os passeadores são colocados em espaços abertos, lado a lado, mas com um afastamento que impeça os galos de se atingirem. Eles comumente são mudados de posição, em busca de sol ou sombra.
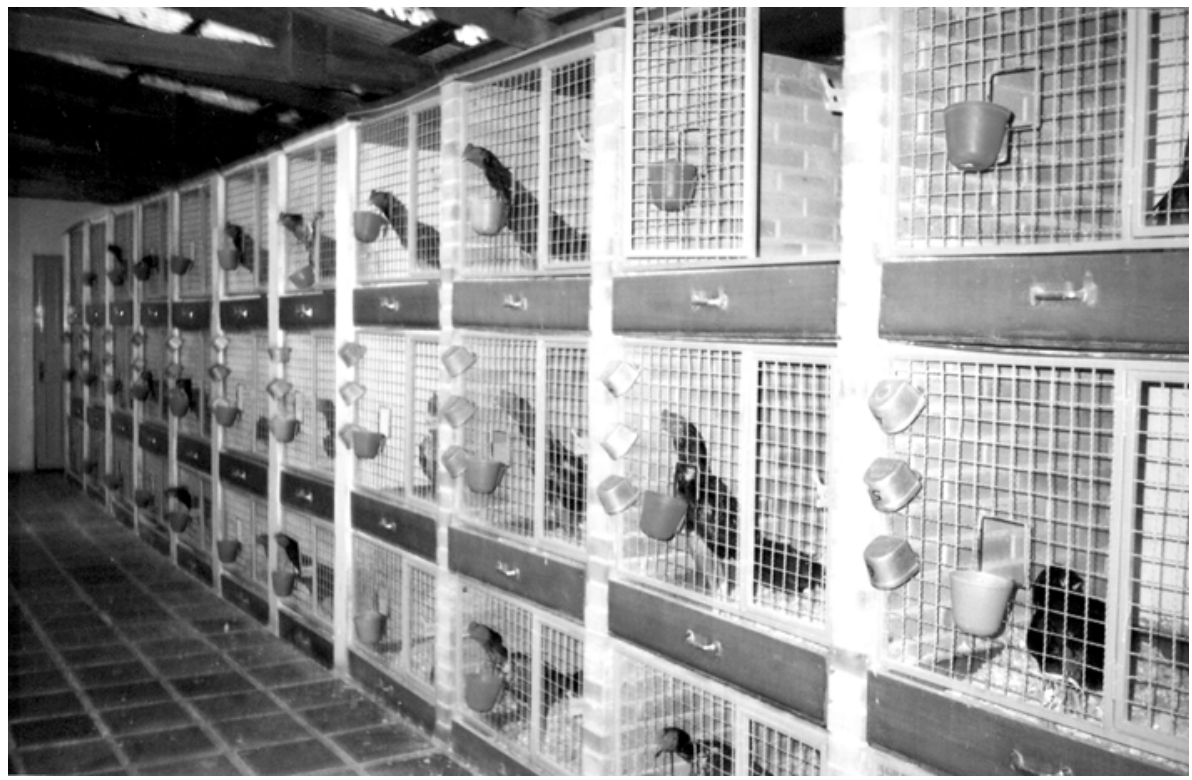

Vista parcial de uma galeria de gaiolas.

O início do treinamento efetivo dos galos é precedido de uma etapa cirúrgica tecnicamente imperativa e, portanto, extensiva a todos eles. As esporas naturais são cerradas deixando um coto com cerca de um centímetro, para permitir a fixação das artificias. A crista, as barbeias e outras "peles soltas" da cabeça são cortadas para diminuir os pontos de apoio à disposição dos adversários, para não facilitar-lhes os golpes. Também são tosadas as penas das pernas e do corpo, junto às asas, deixando a pele totalmente à mostra, para 
permitir o massageamento, com cachaça com infusão de diversas ervas, a fim de estimular o desenvolvimento muscular. A tosa junto às asas visa a também facilitar a ventilação do combatente durante a luta. Ao longo do tempo o corte das penas é renovado, de acordo com as necessidades. As penas mais longas da cauda, por vezes, são aparadas para evitar que os próprios combatentes as pisem no desenrolar das lutas e percam o equilíbrio.

Consolidada a cicatrização dos cortes na cabeça, iniciam-se exercícios diversos, como: ser embalado em um trapézio, dar voltas ao redor de si e ser jogado para frente, para desenvolver equilíbrio; revôo, que consiste em jogar os animais a uma altura de cerca de meio metro, o que também pode ser feito por uma plataforma mecânica que sobe e desce abruptamente, forçando-os a abrirem as asas, para se aprumarem, e assim desenvolver suas musculaturas. Com vistas ao desenvolvimento muscular das pernas também realizam lutas-treino, equipados com peso nas pernas. Assim são levados a baterem com mais força, para superar o peso. Nas fases de treinamentos mais intensivos, cada um destes exercícios são repetidos por cerca de quinze minutos, diariamente. O mesmo se dá com as massagens, em decorrência das quais as pernas dos galos apresentam uma coloração vermelho-vinho.

Os combates-treino que, como regra, ocorrem com o uso de batoques ou buchas, e de biqueiras, também se dão em condições reais, com o uso de esporas de combate. Os primeiros são para os lutadores desenvolverem técnicas de luta e os segundos para “aprenderem a apanhar”. É comum o uso de sparring, geralmente galos experientes, afastados das arenas. As lutas-treino podem se dar também, entre galos de parceiros. Em qualquer situação os galos são observados atentamente pelos seus interessados, para avaliar suas características e orientar suas carreiras. Todas as cocheiras/coudelarias possuem a infra-estrura necessária para tais exercícios, inclusive tambor, e dispõem de um corpo de funcionários. É possível, porém, a um galista com poucos animais atendê-los sozinho. Tais estabelecimentos passam facilmente a impressão de academias de lutas, e os galos equipados com batoques e biqueiras, de boxeadores em treinamento. A comparação pode ser estendida à massa muscular e às técnicas de luta que desenvolvem.

Tudo isto confirma que quando os galistas dizem que os galos são atletas, certamente, eles usam mais do que uma figura de retórica. Ao atingir um ano de idade os galos estão prontos para enfrentar seu primeiro combate. 


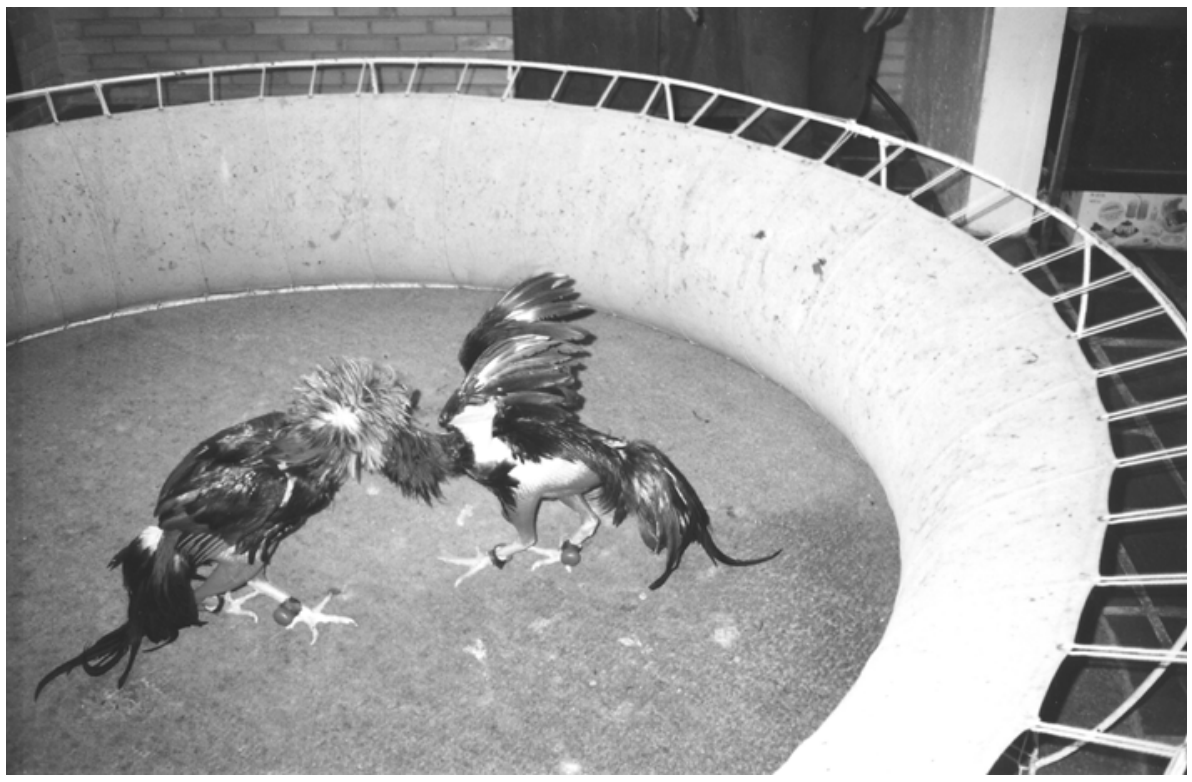

Luta-treino com o uso de batoques e biqueiras.

Somam-se aos esforços para obter bons e poderosos lutadores, uma dieta rica e variada e atenção à saúde. Aos muitos cerais, com destaque para milho, aveia e trigo, adicionam-se carnes, mel, ovos, verduras, sais minerais, vitaminas. A atenção à saúde é preventiva e curativa, incluindo higiene, ambiente salubre (inclusive com ar condicionado), e uma farmácia especializada.

Embora para tudo isto haja recomendações técnicas bastante padronizadas, cada galista tem receitas mais ou menos particulares para preparar e cuidar de seus pupilos, mantendo a respeito um certo segredo. $\mathrm{O}$ mesmo se aplica à vida sexual dos galos, em especial nos períodos que antecedem as lutas. Ressalto que, tanto quanto pude averiguar, todos os cuidados dispensados aos galos são orientados pela racionalidade técnica. Simplesmente não encontrei em tais cuidados nada que lembrasse algo no gênero da magia.

Pelo lado financeiro tais cuidados podem ser duplamente recompensados: aumentam a probabilidade de sucesso nas disputas e a chance de obtenção de bons preços na comercialização de galos. Combatentes de reconhecida procedência podem propiciar ingressos não desprezíveis a seus criadores. O preço de um bom galo, oriundo de uma coudelaria de renome, se situa na 
faixa dos R\$ 2.000,00-4.000.00. O preço mais elevado atingido por um galo, levantado na pesquisa, e considerado como exceção, foi o de $\mathrm{R} \$ 10.000,00$. Pensando num eventual interesse de leitores não familiarizados com o Real, registro que em Dólar dos Estados Unidos a expressão numérica de tais valores é a mesma, no momento.

Embora grande número de galistas criem seus próprios galos, há coudelarias cuja produção é voltada inteiramente para o mercado.

Porque o acordo para a realização de qualquer combate passa pela equiparação dos pesos dos lutadores, todos os confrontos, por princípio, são acertados ad hoc. Usualmente os galos que são levados para o rinhedeiro têm seus pesos registrados num quadro, ao lado dos nomes dos respectivos proprietários. A partir daí começam os contatos para realização das lutas, cuja definição fica condicionada ao acerto quanto ao valor da aposta ou parada entre os proprietários. Pela relevância das apostas nas rinhas a próxima parte - O jogo -, será inteiramente dedicada a considerá-las. O que aí for apresentado, em relação ao Brasil, deverá ser considerado como integrando o padrão brasileiro das brigas de galos.

Nos casos de concentrações ou torneios para os quais são convidados galistas de outros lugares, ainda que os anfitriões devam apresentar um número considerável de galos de diversos pesos, é concedida aos visitantes a preferência para acertar combates entre seus galos. É a regra da cortesia.

A propósito de peso, atualmente no Brasil, os galos se situam numa faixa entre 2,8 e 3,7 kg. Digo atualmente, porque nos últimos quarenta anos houve uma considerável elevação no peso dos galos, decorrente dos esforços dos galistas para a obtenção de combatentes cada vez mais fortes. Os cruzamentos com animais de raças mais pesadas, importados do Japão e Malásia, têm importante contribuição nesta elevação de peso. Estabelecendo uma comparação, indico que no Caribe encontram-se os galos mais leves, com peso em torno de $1,5 \mathrm{~kg}$ e na França os mais pesados, na faixa entre 6 e $8 \mathrm{~kg}$.

Muito variadas no passado, as regras hoje se apresentam quase padronizadas, com mínimas diferenças. Suas principais disposições estabelecem: 1h30min como tempo máximo de duração de cada combate, dividido em rounds de 15 ou 20 minutos, com um intervalo de 2 a 5 minutos entre eles. Na linguagem galística este intervalo é chamado de refresco ou banho. Como já referido, à semelhança do boxe, esta pausa é destinada ao repouso dos combatentes e aos cuidados de seus ferimentos. 
Quando da realização de torneios, o tempo previsto para a duração de um combate pode ser reduzido para o mínimo de uma hora, a fim de permitir a realização de um maior número de confrontos.

Porque as lutas, como regra, terminam quando um dos digladiantes é vencido, as regras que definem as decisões dos combates remetem diretamente àquele e indiretamente ao vencedor. Daí que será considerado perdedor o galo que: a) sofrer tuque (nocaute), o que se caracteriza pela não demonstração de interesse em continuar lutando no transcurso de quinze segundos, caído ou não, após ser atingido por um golpe; b) abandonando a luta, a ela não retornar após cinco tentativas por parte de seu encostador (espécie de segundo no boxe); c) abandonar a luta com cantar de galinha (cocoricar provocado por golpe traumático, cujo som é percebido como próprio de galinha); d) exausto e ferido, sem mais disposição para continuar lutando, não reagir em até cinco tentativas, aos estímulos de seu encostador; e) perder as condições físicas para continuar na luta, por fratura de perna ou asa (a mais comum) ou ainda por cegueira. Para que ocorra a derrota por perda de visão, o proprietário do galo assim atingido deverá reconhecer a derrota, em até cinco segundos após ele ter ficado cego. Reconhecendo a derrota pagará $50 \%$ do valor da parada, sendo o mesmo critério estendido às apostas paralelas. Caso contrário a luta prosseguirá. ${ }^{25}$ Se até o final do tempo programado para a duração da luta nada disso tiver ocorrido, ela será declarada empatada. Nas rinhas não há decisão por pontos, como se dá no boxe.

As regras também determinam que o juiz poderá suspender os combates para a fixação de espora, no momento em que isto eventualmente se fizer necessário, o que é raro acontecer. Pode também anulá-los: a) por doença grave revelada por qualquer galo nos cinco primeiros minutos da disputa; b) a qualquer tempo por falta de claridade natural suficiente ou de iluminação elétrica por quinze minutos consecutivos; c) também a qualquer empo por suspeição de alguma ilicitude. Este último item requer alguns esclarecimentos. Esta suspeição refere-se a galos ilegitimamente preparados para alcançarem a vitória, pelo uso de doping, e de galos corridos, isto é, galos que, condicionados por severos castigos em outras lutas, fogem em qualquer nova disputa, logo aos primeiros golpes sofridos. São inscritos com intenção de propiciarem a seus interessados ganhos em apostas paralelas em seus adversários. Pelo conhecimento dos juízes e dos galistas em geral, dificilmente casos de doping e de galo corrido

${ }^{25}$ Não é raridade um galo cego vencer. 
deixam de ser identificados. Uma vez descoberta a fraude pode-se dizer que os responsáveis são eliminados do meio galístico. Como os galistas compõem uma espécie de grupo corporado, a ofensa é feita a todos seus integrantes. Conforme expressão de um deles “com safado a gente só luta uma vez”.

Troféus, como taças e medalhas e prêmios diversos, são distribuídos aos proprietários/treinadores de galos vencedores de torneios. Os prêmios vão desde os mais simples, como relógios e ovelhas para fazer um churrasco a carros de luxo e tratores, como mostra o convite abaixo reproduzido.

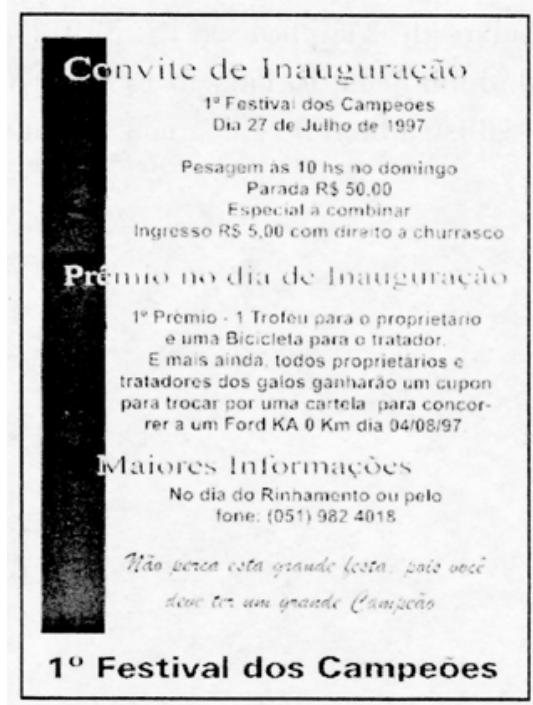

0 jogo

Como já mencionado, o jogo acompanha a rinha em toda a parte, como condição necessária à sua realização. Sendo ela uma modalidade de esporte, como proclamam os galistas, disto resulta uma evidente contradição com aquela condição, se considerados os fatos pela perspectiva da lógica formal: a competição esportiva, em si, exclui o jogo como coisa que lhe seja inerente. Porém, se considerado o fato pela perspectiva de sua lógica substantiva, a contradição se desfaz.

No consenso unânime dos galistas, todo o verdadeiro galista tem que apostar nas rinhas. Este mandamento imperativo foi expresso por vários galistas, de 
maneiras diversas, mas convergentes, como "o jogo é que dá graça às rinhas”; "quem é homem, tem que pagar pelo que diz”; “o jogo é o aval da conversa sobre o andamento da rinha”. Uma leitura mais imediata destas manifestações mostra que apostar nas rinhas é uma maneira de comprometimento com elas e de integração à comunidade galística; uma leitura mais reflexiva, que as considere na concretude do rinhedeiro, revelará sua lógica substantiva: não pode haver briga de galos sem jogo, porque, sem ele, elas ficariam esvaziadas do seu simbolismo essencial. É por isto que mesmo onde o jogo nas rinhas é legalmente proibido, na prática a proibição é francamente ignorada. Tal pode-se dar mesmo na presença da polícia, como na Espanha (Marvin, 1994, p. 197).

A gravura abaixo, de Trujillo, século XVIII, intitulada Riña de gallos, e que integra o acervo da biblioteca do Palácio Real de Madri, ao destacar as bolsas dos apostadores, ilustra bem a relevância do jogo nas rinhas.

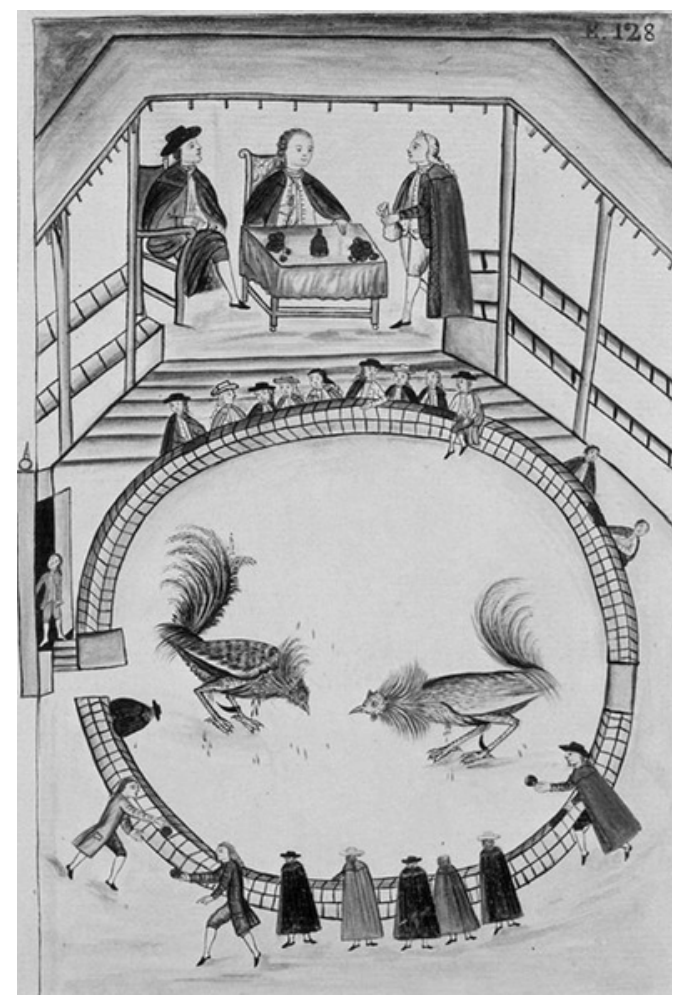


Porém, e atenção para uma advertência, mesmo que o jogo, sempre presente nas rinhas, por regra seja intenso e, por vezes pesado, nada autoriza a definir uma prática pela outra: jogo não é rinha e rinha não é jogo. Daí que, pensando na noção de descrição densa de Geertz (1978, cap. 1), tentarei mostrar por que, como já mencionado, é apenas na aparência que a concepção das rinhas como uma forma de esporte se choca com o jogo como coisa necessária à sua realização. É a aí que entra sua lógica substantiva.

Ainda que a realização de qualquer rinha implique necessariamente na definição de uma aposta ou parada ${ }^{26}$ entre os proprietários dos combatentes e/ou suas parcerias, é no desenrolar dos combates, pelas apostas paralelas, que a obrigação de jogar para poder falar sobre elas e ser reconhecido como galista se manifesta em toda a sua plenitude. O comprometimento dos galistas com o apostar não implica, naturalmente, que devam fazê-lo em todas as lutas a que assistam ou mesmo cada vez que compareçam ao rinhedeiro. É imperativo apostar, isto sim, nos combates em se que têm interesse direto, como proprietário de um dos lutadores ou nos quais se queira apostar. Ainda assim, eximir-se sistematicamente de apostar não é próprio do verdadeiro galista.

Sem dúvida que a idéia de que o "jogo aquece o espírito” (Le Goff, 1973, p. 35), encontra decidida confirmação nas rinhas. De fato, com o espírito aquecido pelo desempenho dos galos, muitos galistas, numa espécie de compulsão, a cada golpe de seus favoritos, são levados a oferecer/aceitar mais e mais apostas. Elas são ao par ou com vantagem. Como é próprio da maneira de combater dos galos que os golpes sejam desferidos em seqüência, com cada um dos combatentes sempre procurando a iniciativa ao longo de cada combate, é fácil imaginar como são intensos os estímulos para apostar, até o último instante. As apostas que, por princípio, são voltadas para a vitória/derrota de um dos combatentes, mais para o final das lutas, também podem se dar no empate.

Por vezes as apostas acontecem em ritmo frenético, acompanhando a seqüência dos golpes desferidos/sofridos. Mesmo com a oferta/aceitação de apostas partindo de muitos pontos e simultaneamente, os aficionados as identificam com absoluta precisão. Elas tanto podem se dar por um simples gesto, monossílabo ou por uma frase desafiadora. Por princípio, todas as apostas devem ser feitas em galos cujos proprietários integrem a parceria do apostador.

${ }^{26}$ Seus valores podem ser definidos quando do acerto do confronto, ou previamente estabelecidos pelo rinhedeiro. 
Todavia, a realização de um combate desaconselhado por um parceiro libera-o de atender a tal princípio.

Porque no desenrolar de cada rinha uma pessoa pode fazer muitas apostas (registrei até mais de vinte), é comum os apostadores anotarem-nas em um pedaço de papel ou pequena caderneta que carregam para tal fim. As apostas são saldadas logo após o término de cada combate, com os perdedores tomando a iniciativa para tanto.

No Brasil, onde quase que por definição, os combates tendem a ser acirrados, prolongados, numerosos e mesmo simultâneos, em dias de lutas os rinhedeiros vivenciam um permanente clima de emoção, marcado por freqüentes piques de exaltação emocional e exacerbação verbal, com os aficionados incentivando seus favoritos e simultaneamente propondo aceitando desafios por meio das apostas.

Ainda que, repetindo mais uma vez, em todos os lugares as brigas de galos tenham o jogo como condição necessária à sua realização, ele tem uma crucial e estrutural diferença de intensidade nas lutas organizadas com maior ou menor probabilidade/previsibilidade de morte em combate. Nas últimas a intensidade do jogo é muitas vezes superior, tanto pelo maior tempo para se apostar como pelos estímulos oferecidos pelo calor dos combates. Das onze lutas a que assisti na França, em apenas duas se concretizaram apostas (três ao todo), durante seu efêmero desenrolar. Nos combates programados para curta duração as apostas paralelas por parte do público tendem a se dar antes de seu início, como em Bali, onde os combates não passam de cinco minutos (Geertz, 1978, p. 294).

Mesmo que apostar nas brigas de galos seja um compromisso do verdadeiro galista, apostar acima de um dado limite, que faz impossível não considerar ou mesmo não privilegiar o aspecto monetário, é tido pelos que assim se consideram, uma distorção do autêntico sentido da rinha. Em tal caso desvirtua-se a disputa esportiva que, pensam, fica sem graça, porque as atenções fixam-se no dinheiro e não na disputa em si. A intenção da aposta é outro tema que também preocupa os verdadeiros galistas. Para estes, apostar nas rinhas tem o sentido de comprometimento com elas enquanto prática esportiva. Daí as freqüentes críticas que fazem aos falsos galistas, isto é, aqueles que procuram os rinhedeiros como alternativa aos cassinos, o que, definitivamente eles não são. Geertz (1978, p. 300) posiciona-se da mesma forma quando diz que “a briga de galos não é uma roleta”. Daí, que não é o valor apostado, em si, mas a intenção da aposta, que distingue o falso do verdadeiro galista. Cegarra (1988, p. 57) faz o mesmo tipo de consideração para a França. 
Certamente, é por tais coisas que, mesmo havendo uma tendência generalizada de desconfiança quanto à honorabilidade/credibilidade financeira das pessoas que têm o hábito de jogar, tal não sucede com respeito aos galistas. O setor de cadastro bancário, especialmente sensível à questão, serve de exemplo. Enquanto é bastante comum que ele oponha restrições a turfistas por esta condição, o mesmo não se dá pela condição de galista, o que faz sentido, pois o jogo nas brigas de galos não contempla a conotação de vício.

Ao falar das apostas nas rinhas, não pressuponho que o dinheiro não importe, para galistas do Brasil ou de qualquer outro lugar. Importa e muito.

Afora a questão geral de que ninguém põe dinheiro fora em sentido literal e que ganhá-lo é bom, o jogo de cobertura e a utilização da possibilidade de suspensão de um combate em andamento, por iniciativa de um proprietário, em função da inferioridade de seu galo, mostra bem o interesse dos galistas em minimizar a possibilidade/probabilidade de perdas nas rinhas.

Jogo de cobertura são apostas com o recebimento de considerável vantagem, feitas contra o próprio galo ou em outro em que se tenha apostado, quando muito superiores no combate. Com este tipo de aposta os galistas previnem-se contra uma sempre possível inversão da tendência de uma luta. Confirmando-se a tendência do combate deixa-se de ganhar um pouco; em compensação, revertendo-se tendência diminui-se a perda.

A oferta de suspensão de combate é tentada pelo galista quando a inferioridade do seu galo é considerável, mas ainda com chance de uma sempre possível reversão da situação. Ele oferece pagar não menos de $50 \%$ do valor da parada. Feito o acerto com o proprietário do galo adversário o combate poderá ser suspenso, com a autorização do juiz. Em tal caso o perdedor livra-se de uma provável maior perda; o vencedor ganha menos para evitar uma improvável mas sempre possível perda maior; em tais casos as apostas paralelas entre os demais participantes são anuladas.

Ressalto todavia que a preocupação com ganhos e perdas financeiras nas rinhas não se vincula à orientação de minimizar custos e maximizar lucros aplicada aos empreendimentos econômicos, o que elas não são. Muito ao contrário, elas se constituem, também, numa forma de atividade derivativa à rotina, mais ou menos enfadonha, da vida diária, como se dá com sítios de lazer, turismo, esporte amador, etc., cuja contabilidade considera menos as questões financeiras e mais as satisfações pessoais. 
De modo muito peculiar, as brigas de galos não se prestam para o jogo à distância, com os apostadores afastados do cenário das disputas, como pode se dar com as corridas de cavalos, partidas de futebol e outras competições esportivas. É pressuposto necessário para apostar nas brigas de galos que os apostadores estejam presentes e atentos ao que se passa em cada combate em que apostam. Tanto pelo lado operacional, as lutas são definidas praticamente na hora de sua realização, como pelo simbólico, os apostadores devem estar presentes ao seu desenrolar.

Ainda que se possa saber com exatidão o valor de muitas apostas, será muito relativa a validade de qualquer classificação, que as coloque numa escala que vai do baixo ao alto. Evidente que a avaliação de uma aposta, nestes termos, remete ao patrimônio dos apostadores e não aos valores absolutos que são apostados. Ainda assim, como um termo de referência, forneço alguns valores. Os valores mínimos das paradas no rinhedeiro de Porto Alegre onde pesquisei e no Clube Privé 5 Estrelas, do Rio de Janeiro, no momento, estão fixados, respectivamente, em R \$ 100,00 e R \$ 5.000,00. Em ambos os casos tais valores são com freqüência ultrapassados, em até muitas vezes. Em Porto Alegre o valor da maior parada registrado pela pesquisa foi de $\mathrm{R} \$ 10.000,00$. No rinhedeiro de Rio Pardo as paradas dificilmente ultrapassam os R\$200,00. Para o Brasil, foi encontrado Cz\$500.000,00, equivalentes a US\$ 37.000,00, pela sua cotação na época, como o maior valor de uma parada. Ocasião em que, com o rinhedeiro superlotado, "todo o mundo largou o rebolo e se concentrou no tambor para ver a grande briga das 500 milhas cruzadas”. ${ }^{27}$ Este valor foi considerado pelos muitos galistas consultados a respeito, como exceção "fora de qualquer sentido", "um despropósito”, “uma coisa de loucos”, conforme expressões de três deles.

As apostas paralelas apresentam variações muito maiores. Os valores mínimos e máximos que vi ofertar/aceitar, em Porto Alegre, foram de R $\$ 20,00$ e R \$ 500,00. Não é incomum que os valores em apostas paralelas apostados individualmente num dado combate ultrapassem o valor da parada para ele estabelecida. Inclusive o proprietário de um galo em combate pode investir em apostas paralelas valor superior ao de sua participação na parada.

27 Noticias da Rinha, n. 4, 1986, p. 11. Cz\$/Cruzado era a moeda brasileira da época e o combate foi realizado no Torneio de Cuiabá, em agosto de 1986. 


\section{0 simbólico}

Inicio a abordagem do simbolismo essencial das rinhas pensando que o mesmo se vincula, inerentemente, à questão do masculino e do feminino, sempre presente em toda e qualquer sociedade. Não interessa, aqui, discutir o fato mas, tão somente, registrar que se trata de um dado da condição humana, que as concepções e realidades individuais e sociais orientam no sentido da oposição/ complementação ou exacerbação/ocultação mais ou menos nítidas, nas diferentes áreas da vida sócio-cultural. Assim sendo, no fundo, a questão do gênero nunca é superada. Daí que, por sua relevância para a vida social, a questão do masculino e do feminino sempre se manifesta, prática ou simbolicamente. Feito isto passo de imediato a considerar a proposição do vínculo necessário do sentido simbólico das rinhas com a questão do masculino e do feminino.

Este vínculo que é direto e positivo com o masculino é indireto e negativo com o feminino é posto em evidência nas rinhas, com a exaltação teatralizada de determinados atributos, pensados como inerentes à masculinidade em sua dimensão moral.

A afirmação de um princípio pela negação ou ocultação de seu oposto é estratégia social comum, e muito satisfatoriamente apoiada em Turner (1980, p. 45, tradução minha) quando diz que "qualquer ritual maior que destaque a importância de um único princípio de organização social, só pode fazê-lo bloqueando a expressão de outros princípios importantes”. Ao reconhecer a integral validade deste pensamento, obviamente, reconheço a feminilidade como importante princípio de organização social e que as brigas de galos podem ser pensadas como rituais seculares. No caso, rituais de confirmação dos atributos morais da masculinidade anteriormente já referidos: brio, coragem, estoicismo, dignidade.

Por serem momentos especiais, como "extraordinários programados" de que fala DaMatta (1979, p. 37), as rinhas se constituem em um tipo de ritual secular. ${ }^{28}$ Mônica Wilson (apud Turner, 1974, p. 19) mostra o grande potencial explicativo dos rituais ao dizer que eles

[...] revelam os valores no seu nível mais profundo [...] os homens expressam no ritual aquilo que os toca mais intensamente e, sendo a forma de expressão

${ }^{28}$ Ver Moore e Myerhoff (1977) e Riviere (1995). 
convencional e obrigatória, os valores do grupo é que são revelados. Vejo no estudo dos ritos a chave para compreender-se a constituição essencial das sociedades humanas.

Nas rinhas, a vinculação do masculino com o positivo e do feminino com o negativo se dá de modo duplo e sem qualquer ambigüidade: pela exaltação de atributos concebidos como masculinos e pela estigmatização de outros concebidos como femininos, a partir do desempenho dos galos em combate. Tanto por seu móvel como por seu agente, nada disto se dá por acaso.

A teatralização que, no caso, exalta as posturas tidas por masculinas e estigmatiza as tidas por femininas, se dá em obediência a um imperativo universal da vida social: salientar o valor de princípios estruturais, tidos por axiomáticos, como parte dos procedimentos para prevenir sua quebra ou corrigir os danos provocados por ela, reforçando-os em ambos os casos.

Porque as brigas de galos dizem respeito ao primeiro caso é dele que tratarei.

Como já disse que as brigas de galos exaltam manifestações como brio, coragem, etc., pensadas como atributos maiores e inerentes à masculinidade, em sua dimensão moral, impõe-se considerar porque são pensados de tal modo.

Falo em dimensão moral e, portanto, em atributos morais, porque em toda parte, a manifestação concreta de qualquer deles é, sempre, atribuída a um ato de vontade de quem a ostenta. Congruentemente, o mesmo também é pensado da manifestação de atributos inversos.

Falo em atributos maiores e inerentes à masculinidade, porque também em toda a parte, eles são exigidos por todos, dos indivíduos masculinos, desde que dotados de um certo mínimo de capacidade de uso da vontade. Daí que, da infância à velhice, a exibição de tais atributos é cobrada, honrada e, também, punida, quando não se concretiza. Com isto, se estou dizendo que estes atributos são dispensáveis para a expressão da feminilidade em sua dimensão moral, não estou negando que mulheres possam exibi-los nem que os mesmos não lhes possam ser exigidos. Todavia, neste caso, tal se dá por vinculação a desempenhos esperados de determinados papéis sociais, por elas representados e, não, para confirmação de atributos de gênero, como se dá em relação aos homens.

Ritos de passagem masculinos nas sociedades simples; ritos de exaltação e degradação em instituições militares nas sociedades complexas, como 
eventos institucionais programados para colocá-los em primeiro plano, servem para ilustrar a vinculação, pensada como inerente, entre aqueles atributos e masculinidade moral.

Os primeiros para cobrar dos jovens a demonstração de já possuírem tais atributos. ${ }^{29}$ Os segundos para exaltar ou degradar os militares que, comprometidos com eles, por juramento, honraram ou não o compromisso. Exemplos dos últimos têm considerável presença nos meios de comunicação social, incluído aí o cinema.

A caracterização de brio, coragem, etc. como atributos maiores da masculinidade também encontra confirmação na comparação com seus atributos físicos, como virilidade e vigor. Bem antes de possuir estes, aqueles já são incutidos e exigidos dos meninos; com o passar do tempo aumenta a indulgência para os homens maduros, que chega à aceitação total na velhice, para a perda da virilidade e vigor, enquanto se passa o inverso com os atributos morais.

Porque os galos são pensados como ostentado aqueles atributos é muito natural que seus combates se constituam em agência especial para colocá-los em evidência.

Abstraindo quaisquer outras considerações, todas as pessoas com experiência em rinhas, mesmo que não aficionadas por elas, certamente, pensarão os galos como possuidores daqueles atributos, em grau superlativo. Se, para os não aficionados, esta avaliação, muito provavelmente se dá a nível das representações, para os galistas ela é real: os galos, de fato, possuem aqueles atributos. Isto porque, quanto mais amplo for o envolvimento de uma pessoa com as rinhas, mais arraigada será sua convicção de que um galo fugir da luta, deixar de revidar os golpes do adversário ou não demonstrar a intenção de fazê-lo, mesmo que tenha perdido as condições físicas para tanto, são fatos raros, que só se dão após o combatente ter sido submetido a severíssimos castigos por parte de seu oponente. É freqüente que um galo, mesmo à mercê de seu opositor, demonstre disposição de continuar na luta (o que só não se concretiza porque a luta é encerrada). Por mais que alguém possa se revoltar ou penalizar-se ante um quadro como este, não deixará de perceber o brio, a coragem, o estoicismo, a dignidade demonstrados pelos galos e, possivelmente,

${ }^{29}$ Ver Service (1963). 
comover-se. Por isto é fácil compreender as emoções que as rinhas despertam naqueles que captam seu simbolismo essencial, como Braun (1979, p. 29-31) no seu poema "Galo de rinha”, transcrito a seguir:

Valente galo de briga,

- Guasca vestido de penas! -

Quando arrastas as chilenas

No tambor de um rinhedeiro,

No teu ímpeto guerreiro

Vejo um gaúcho avançando

Ensangüentado, peleando

No calor do entrevero!

Pois assim como tu lutas

Frente a frente, peito nu,

Lutou também o chiru

Na conquista deste chão...

E como tu - sem paixão,

Em silêncio - ferro a ferro,

Caía sem dar um berro

De lança firme na mão!

Evoco nesse teu sangue

Que brota rubro e selvagem,

Respingando na serragem,

Do teu peito descoberto,

O guasca no campo aberto,

De poncho feito em frangalhos,

Quando riscava os atalhos

Do nosso destino incerto!

Deus te deu, como ao gaúcho

Que jamais dobra o penacho,

Essa altivez de índio macho

Que ostentas já quando pinto;

$\mathrm{E}$ a diferença que sinto

É que o guasca - bem ou mal! -

Só luta por um ideal

$\mathrm{E}$ tu brigas por instinto! 
Por isso é que numa rinha

Eu contigo sofro junto,

Ao te ver quase defunto,

De arrasto, quebrado e cego,

Como quem diz: - 'Não me entrego;

Sou galo; morro e não grito

Cumprindo o fato maldito

Que desde a casca eu carrego!’

E ao te ver morrer peleando

No teu destino cruel,

Sem dar nem pedir quartel,

Rude gaúcho emplumado

Meio triste, encabulado,

Mil vezes perguntei -

Por que é que não me boliei

Pra morrer no teu costado? -

Porque, na rinha da Vida

Já me bastava um empate!

Pois cheguei no arremate

Batido, sem bico e torto...

E só me resta o conforto

Como a ti, galo de rinha,

Que se alguém dobrar-me a espinha

Há de ser depois de morto!

A propósito da equiparação de comportamentos masculinos com a marca de coragem, destemor, dignidade, percebidos como próprios dos homens de verdade à bravura dos galos, entendo oportuno referir que isto é uma tendência geral no mundo. No Brasil, expressões do tipo cantar de galo; no meu terreiro só eu canto; ele pensa que é galo; deu uma (demonstração) de galo; fulano é metido a galo, são usuais e ilustram adequadamente a afirmação. Mesmo que na mente da maioria das pessoas ao proferirem tais sentenças não surja a figura do galo de briga, sem dúvida que sua origem vincula-se a ele. De fato, só ele exibe, sempre, a disposição para lutar, de buscar a vitória por si mesma.

Em consonância com isto é freqüente a literatura técnica, por definição também comprometida com a defesa da legitimidade social das rinhas, 
apresentar a clássica exortação de Temístocles aos soldados atenienses sob seu comando que enfrentariam os persas (século V a.C.), ao se deparar com uma briga de galos: "Vejam esses animais! Eles não brigam por seus deuses, por glória, liberdade, por seus ancestrais ou em defesa de sua prole, mas simplesmente porque um não quer se submeter ao outro" (cf. Elias, 1978, p. 22).

Numa espécie de parênteses registro que, mesmo discordando da associação rinhas/sexualidade proposta por Dundes e, nisto ele tem a companhia de autores consagrados como Bateson e Mead (1942), também reconheço uma explícita associação galos/sexualidade masculina, largamente difundida no Brasil. Todavia, é importante registrar ela não remete às rinhas. Tal associação, além de se dar por referência a galos em geral e não a galos de briga em particular (como também deve se dar em outros lugares), integra os códigos da sexualidade com sinal negativo. Assim que, comparar um homem a um galo, em termos de sexualidade, é dizer que qualquer mulher lhe serve; que ele não tem critérios; que ele não tem poder de escolha/sedução com mulheres de classe; que ele é mau parceiro por atingir o orgasmo muito rapidamente. A associação galinha/sexualidade feminina, que também integra aqueles códigos, tem o mesmo tipo de sinal. Comparar uma mulher a uma galinha, em termos de sexualidade, é dizer que ela cede ou se oferece para qualquer um; que não tem classe; que é vulgar; que é parceira potencialmente perigosa pela probabilidade de transmitir doenças venéreas.

Agora, outra vez, retomo a análise comparativa entre as rinhas organizadas com ou sem probabilidade/previsibilidade de morte em combate.

No caso em que a morte é posta em evidência as lutas são organizadas como que reproduzindo o estado de natureza, para os galos exibirem o que é pensado como sendo seus atributos naturais maiores como lutadores: lutar até o fim pela vitória com disposição para matar/morrer.

No caso onde a morte não é cogitada, as lutas são organizadas para os galos exibirem os atributos que são pensados como inerentes à masculinidade, em sua dimensão moral.

Assim, minha proposição básica, é que os combates do primeiro tipo apontam para o domínio da natureza e que os do segundo apontam para o domínio da cultura.

Ao pensar assim não estou dizendo que os aficionados por um ou outro tipo de combate tenham percepções diferentes a respeito dos galos de briga 
como lutadores inatos e valentes. Estou dizendo, isto sim, que eles organizam as coisas de modo a que os galos exibam, com ênfase, determinadas características que lhes são próprias e que interessam aos organizadores de suas lutas.

No primeiro caso o que é valorizado pelos aficionados, que mais explicitamente lhes desperta o interesse, é a competência, a habilidade dos lutadores em logo liquidar o adversário. Para tanto exacerbam a natureza, equipando os galos com armas mais letais que as naturais. Apresentada a questão a Danaë ele entendeu-a pertinente. Em situação natural, as lutas que, por princípio, só terminam com a morte de um dos digladiantes, se prolongam por muito mais tempo do que os cinco minutos que costumam durar nos rinhedeiros com o uso de armas letais.

No segundo caso, o que é valorizado pelos aficionados, que também mais explicitamente lhes desperta o interesse, são as demonstrações dos atributos morais da masculinidade. Para tanto controlam a natureza, equipando os galos com armas não letais e treinando-os como atletas. Assim as lutas podem se prolongar por muito mais tempo do que em situação de natureza. Esta interpretação foi reconhecida como correta pelos quatro galistas que atuaram como consultores na etapa final da pesquisa.

Para evitar qualquer dúvida, explicito que os aficionados por um ou outro tipo de rinhas trabalham, axiomaticamente, com a noção de brio, coragem, etc., dos galos e deles mesmos. Isto é inerente àqueles que, real ou metaforicamente (com risco efetivo de perdas importantes), enfrentam a morte e a dor com destemor. Para mim, aí é que radica o simbolismo essencial das brigas de galos, sempre presente e que preside a realização de todas elas. Quaisquer outros simbolismos que elas possam apresentar são secundários em relação àquele.

Ainda assim, também entendo que os atributos morais da masculinidade se projetam com mais evidência nos combates organizados com improbabilidade/impossibilidade de provocar a morte. Isto porque, neles, o tempo para que a dor e sofrimento sejam vivenciados é intencionalmente prolongado. Acrescente-se ainda que a morte, apesar de ser o fato mais radical da vida é, também, o instrumento mais radical para superar a dor e o sofrimento. Implorar pela morte, eutanásia e suicídio se inserem aí.

Para que os atributos morais da masculinidade se manifestem com maior evidência é preciso mais do que treinar e equipar os galos com armas não 
letais para se enfrentarem em combates de longa duração. É necessário um trabalho mental para que galistas e galos sejam representados como homens de verdade, por exigirem a posse daqueles atributos.

Entendo que a primeira coisa a fazer para a boa compreensão da questão é considerar uma preliminar básica, em aparente contradição com postulado de que os atributos morais da masculinidade se manifestam por ato de vontade. Refiro-me à postulação de um vínculo necessário entre estes atributos e genitália masculina.

Marvin, que aborda as rinhas na Espanha, muito próximas do padrão brasileiro, faz importantes considerações a respeito de tal vinculação. Depois de citar Brandes para quem "o locus do poder e vontade, das emoções e força, estão nos genitais masculinos, [...] os homens falam como se eles fossem impelidos a agir de acordo com opiniões e desejos que estão nos testículos e no pênis”, e Corbin, que diz "a bravura é pensada como tendo uma base fisiológica - força de caráter é equiparada com 'ter bolas”” (ambas citações em itálico), ele próprio afirma "um verdadeiro homem possui cojones (grifo dele) [...]; é isto que permite ele agir como um homem deve agir; ter cojones permite a um homem agir nas circunstâncias difíceis e perigosas” (Marvin, 1994, p. 182, tradução minha).

No Brasil, a referência, a ter ou não, colhões, para enfrentar uma situação difícil ou de risco, que exige coragem, ousadia, é bastante comum. A indignação, que costuma exacerbar o apelo a esta forma de expressão, por vezes também adjetiva os colhões de roxo, para enfatizar seu poder. A situação pode ser exemplarmente ilustrada por um episódio bastante recente, com ampla divulgação pelos meios de comunicação social. Fernando Collor, quando Presidente da República, ao ser apupado por um grupo de manifestantes, indignado, e mostrando sua disposição de enfrentá-los disse ter "aquilo roxo”. Colhudo, com registro nos dicionários, também é sinônimo de valentão. Vinculado a tudo isto também se diz que um homem tem que honrar o que tem entre as pernas e que mulheres que agem com arrojo, coragem, etc., possuem ou parecem possuir colhões. Assim fica claro o porquê de ser aparente a contradição que vincula atributos morais da masculinidade a testículos. Igualmente, também fica claro que, ao ser pensado como exclusividade da parcela masculina da espécie humana a condição para exibir aqueles atributos, projeta-se a relevância das representações para a construção do social, como 
mostra o preciso juízo de Nietzsche sobre a espécie humana, quando diz que a "ilusão é a essência que o homem se criou".

Alargando a abrangência da concepção de testículos como fonte de uma força de natureza não física, me parece oportuno uma referência às estátuas eqüestres de heróis e chefes eminentes erguidas mundo afora. Certamente elas incorporam esta concepção. Não será por mero acaso, nem por cânones artísticos, que quase todos eles, os heróis e chefes eminentes, que por definição, devem ostentar atributos como brio, coragem, dedicação a uma causa, etc., têm por montaria colhudos, com os testículos em evidência. Como exceção que confirma a regra, o único monumento, que sei, em que um herói monta uma égua, é o de Pancho Villa, na Cidade do México. No caso a alegoria foi fiel aos fatos: ele está representado em sua montaria favorita, a égua Siete Leguas.

No Brasil associação testículos/vontade também encontra plena expressão na equiparação, corrente num passado não muito remoto e hoje quase em total desuso, entre galo capão e homem acovardado. A associação é perfeita: galo capão é destituído de qualquer disposição para enfrentar outros animais de sua espécie. Foge até de galinha. Daí que, emblematicamente, homem que é dominado pela mulher, é equiparado a galo capão. Ressalto, todavia, que o desuso da associação deve-se não a seu esvaziamento por perda de pertinência simbólica, mas ao abandono da prática de castrar frangos, como decorrência natural do criatório industrial de galinhas, com o desenvolvimento de raças próprias para a produção de carne. Como se dá com machos de todas as espécies animais criadas para produção de alimentos, os frangos eram castrados para produzir mais e melhor carne.

Retomo agora a questão do trabalho mental para que galistas e galos sejam representados como homens de verdade. É no desenrolar do ritual das lutas, pelo comportamento de homens e animais, que se dá esta representação. DaMatta (1978a, p. 11) contribui para a compreensão do peso do ritual na operação deste fenômeno ao dizer que “[...] ritos e atos teatrais, essas ações que tornam a rotina diária senão suportável ou justa, pelo menos revestem-na com um certo toque de mistério, dignidade e elegância”.

Através das apostas, arriscando-se, expondo-se ao perigo real de perder, mostrando que têm brio, coragem, etc. os galistas se proclamam e se fazem reconhecer como homens de verdade, formando uma comunidade de pares, que exige como condição necessária para integrá-la ter colhões, em sentido 
real e metafórico. Aí, acredito, encontra-se a chave para explicar porque as rinhas são um nicho de masculinidade. Às mulheres falta a condição essencial para integrar aquela comunidade de pares. Assim, a não presença de mulheres nas rinhas tem raízes no simbólico e não numa suposta natural/cultural incompatibilidade com violência. Afinal, a presença feminina em touradas e lutas de boxe é sabidamente expressiva. A propósito também cabe o registro de que práticas esportivas como futebol, ainda tida por muitos como prática masculina, está deixando de sê-lo. Pela primeira vez, nos recentes Jogos Olímpicos de Atlanta, o futebol feminino integrou o elenco das modalidades em disputa.

Já a representação dos galos como homens de verdade se dá pelo comportamento dos galistas e lutadores.

“Dá na cara dele”, expressão freqüente nas rinhas, e que na aparência é para estimular um ou outro combatente mas, que de fato, expressa um desejo de quem a pronuncia, serve bem para iniciar a apreciação deste assunto. Ela projeta uma questão simbólica relevante. "Dar na cara” é próprio de brigas entre homens reais. Em suas brigas, "dar na cara” ou mesmo ameaçar fazê-lo é coisa muito grave. Ao assim proceder, o agressor mostra que está preparado para o que der vier, que é homem para agüentar as conseqüências de sua atitude. É certo que ela mexerá com os brios do agredido, se ele for homem de verdade. De fato, mesmo pessoas mais contidas sentem-se no dever de reagir a ofensa tão grave à sua honra. A associação que Pitt-Rivers (1979, p. 22-23) estabelece entre cabeça/rosto e honra/dignidade aponta na mesma direção. Por tais coisas, ao gritarem para um galo "dar na cara do outro", os galistas pensam-nos como sendo homens de verdade. Apresentada esta interpretação a sete galistas, dois mostraram-se sem condições de avaliá-la, quatro admitiram-na como coerente e um concordou plenamente, acrescentando "dar na cara é coisa de homem e homem de verdade não apanha na cara sem dar o troco. Tem que bater."

Ainda que durante todo o combate seja processada a representação dos galos como homens de verdade, é no final dos combates mais longos, que ultrapassam uma hora de duração, que o processo atinge seu ápice. Nesta altura do combate, com os digladiantes cansados e feridos, porém mantendo a galhardia, predomina um quase silêncio. Os golpes, que de início eram freqüentes, ruidosos e frenéticos agora são espaçados, quase silenciosos e lentos. As apostas, antes gritadas, agora são encaminhadas por gestos ou sussurros. 
A contenção espontânea e inevitável dos homens reais, e que também se pensam homens de verdade, se impõe no final dos combates, como reconhecimento àqueles que lutam como homens de verdade.

Por um princípio lógico, se tanto falei na idéia de homens de verdade, construída na cabeça dos galistas, esta mesma cabeça também constrói, através de comportamento dos galos tido por negativo, a idéia de homens não verdadeiros. Eles se caracterizam, logicamente, por atributos morais opostos aos que caracterizam os homens de verdade.

Os galos que apresentam comportamento negativo não são, por definição, todos os derrotados. São apenas os que perdem por covardia, que fogem da luta. Aos derrotados, mas que lutaram com bravura, estende-se o reconhecimento de galos/homens de verdadeiros, de modo análogo ao que se dá com homens reais. No mundo dos esportes, o futebol profissional, ilustra bem a situação. Os atletas que, como regra recebem uma gratificação por vitória, o bicho, também podem recebê-lo em caso de empate e, mesmo, de derrota, quando se empenham com denoto para vencer. Em tais casos é comum falar-se em vitória moral e dizer-se que caíram de pé. As muitas histórias, ainda que fictícias, de homens que embora vencidos em combates mortais, mas que pela bravura com que lutaram tiveram a vida poupada para tirar cria, como reconhecimento do vencedor, se enquadram na mesma ordem de consideração.

É percebido como covarde o galo que foge, que abandona a luta, sem ter sido severamente atingido pelo adversário. Tais derrotas abalam o ânimo do seu proprietário. Tive a oportunidade de entrevistar um galista, quatro dias após um de seus galos ter fugido da luta quando esta estava à sua feição. Na linguagem galística ele largou de cima (abandonar a luta sem razão aparente, quando em ampla vantagem). Disse-me ser eu a primeira pessoa com quem falava, afora aquelas "de compromisso, desde aquele dia terrível. Foi covarde o galo e foi covarde o homem.”

O renomado galista Seitenfus (1975, p. 37) expressa sentimento análogo ao dizer que "todo o verdadeiro galista abomina perder por falta de brio de seu galo”. Por sua vez isto mostra que as lutas de galos são lutas verdadeiras e não uma pantomima como as lutas de catch, assunto tão bem considerado por Barthes (1982, p. 11-21).

Porém, de todas as derrotas por covardia, uma se sobressai a qualquer outra: aquela com o cantar de galinha, isto é, quando, como já referido, 
o galo, por um golpe mais traumático abandona a luta e, por dor, emite um som baixo, entendido como um cocoricar de uma galinha. Enfim, com isto, ele demonstra que abandonou a luta pela dor. A um galo/homem de verdade isto não é concedido. Vargas (1986, p. 208) para o México e Marvin (1994, p. 180), para a Espanha, também registram o cantar de galinha como covardia maior. Neste caso o galo é feminilizado, sempre em sentido moral. Poucos dias depois de perder uma rinha com cantar de galinha, disse-me um galista que ficou "arrasado, porque o galo virou galinha e ele mulher."

Estas manifestações também apontam para uma identificação mais direta entre galistas e seus galos, em combate. O mesmo se dá quando da oferta/ aceitação de apostas, eles são identificados pelos nomes/apelidos pelos quais seus proprietários são conhecidos nos círculos galísticos.

Aos destacar que as rinhas exaltam a dimensão moral da masculinidade não estou dizendo que os galistas não busquem a vitória pessoal através de seus galos. Buscam-na com paixão. Por isto, quando a vitória é alcançada, “o galista se engrandece e se faz respeitar”, como disse um deles. Os esforços para obtê-la é a contribuição individual de cada galista, para exaltar os tantas vezes referidos atributos morais da masculinidade.

Por tudo que disse me sinto à vontade para parafrasear García Lorca quando diz ser a tourada "o único lugar onde se vai com a segurança de ver a morte rodeada da mais deslumbrante beleza” (cf. Amorós, 1988, p. 170, tradução minha). Digo que o rinhedeiro é o lugar por excelência onde o afrontamento da morte/sofrimento é solenizado e partilhado por todos.

Por princípio, este sentimento é partilhado por todos porque os rinhedeiros não se constituem em espaços para espectadores desinteressados do que se passa no tambor/rebolo. Muito ao contrário, eles se constituem em espaços para a participação interessada do que se passa naquelas arenas.

É da maior importância destacar que as brigas de galo não comportam a partilha de interesses com o que se passa ao seu redor, como se dá com apresentações teatrais e com corridas de cavalos, em especial nas chamadas noites ou tardes de galas. Nestas oportunidades o que se passa nos palcos e pistas sofre a concorrência do que acontece nos camarotes, tribunas e salões. Nas rinhas, as galas concentram-se nas arenas. 


\section{Referências}

ALKEN, H. The national sports of Greal Britain. London: [s.n.], 1825.

AMORÓS, A. Toros y cultura. Madrid: Espasa-Calpe, 1988.

BARTHES, R. Mitologias. São Paulo: Difel, 1982.

BATESON, G.; MEAD, M. The balinese character: a photografic analysis. New York: New York Academy of Sciences, 1942.

BRAUN, J. C. De fogão em fogão. Porto Alegre: Sulina, 1979.

CAILLOIS, R. Os jogos e os homens. Lisboa: Cotovia, 1990.

CAMPELLO, L. B. Campeões da arena. Campo Grande: Brasil Galístico, 1954.

CANTA CLARO. México, año 35, n. 2, 1991.

CEGARRA, M. Les coqs combattants. Terrain, Paris, n. 10, 1988.

DAMATTA, R. Apresentação. In: GENNEP, A. van. Os ritos de passagem. Petrópolis: Vozes, 1978a.

DAMATTA, R. O ofício do etnólogo, ou como ter anthropological blues. In: NUNES, E. (Org.). Aventura sociológica. Rio de Janeiro: Zahar, 1978b.

DAMATTA, R. Carnavais, malandros e heróis. Rio de Janeiro: Zahar, 1979.

DANAË, O. Combacs de coqs: histoire et actualité de l'oiseau guerrier. Paris: L'Harmattan, 1989.

DINWIDDIE, W. Cock-fighting in Puerto Rico. In: DUNDES, A. (Ed.). The cockfight: a casebook. Madison: The University of Wisconsin Press, 1994.

DUNDES, A. Gallus as phallus: a psychoanalytic cross-cultural consideration of the cockfight as fowl play. In: DUNDES, A. (Ed.). The cockfight: a casebook. Madison: The University of Wisconsin Press, 1994a. 
DUNDES, A. (Ed.). The cockfight: a casebook. Madison: The University of Wisconsin Press, 1994b.

ELIAS, F. Galos de briga e brigas de galos. Rio de Janeiro: [s.n.], 1978.

GARCÍA MÁRQUEZ, G. El coronel no tiene quien le escriba. 9. ed. México: Era, 1973.

GEERTZ, C. A interpretação das culturas. Rio de Janeiro: Zahar, 1978.

GUGGENHEIM, S. Cockfighting in Philippines. In: DUNDES, A. (Ed.). The cockfight: a casebook. Madison: The University of Wisconsin Press, 1994.

HALLEY, A. Roots. New York: Dell, 1977.

LEAL, O. F. The gaúchos: male culture and identity in the Pampas. 1989. Ph.D. dissertation, University of California, Berkeley, 1989.

LEAL, O. F. The gaucho cockfight. In: DUNDES, A. (Ed.). The cockfight: a casebook. Madison: The University of Wisconsin Press, 1994.

LE GOFF, J. Os intelectuais na Idade Média. Lisboa: Estúdios Cor, 1973.

MACIEL, M. E. de S. Le gaúcho: l’identité culturelle dans le Sud du Brésil. 1994. Thèse de doctorat, Paris V, Sorbonne, Paris, 1994.

MARVIN, G. The cockfight in Andalusia. In: DUNDES, A. (Ed.). The cockfight: a casebook. Madison: The University of Wisconsin Press, 1994.

McCAGHY, C. H.; NEAL, A. G. The fraternty of cockfighters: ethical embellishments of an illegal sport. In: DUNDES, A. (Ed.). The cockfight: a casebook. Madison: The University of Wisconsin Press, 1994.

MOORE, S. F.; MYERHOFF, B. G. (Ed.). Secular ritual. Assen: Van Gorcum, 1977.

OLIVEN, R. G. A parte e o todo: a diversidade cultural no Brasil-nação. Petrópolis: Vozes, 1992. 
PITT-RIVERS, J. Antropologia del honor o política de los sexos. Barcelona: Crítica, 1979.

RIVIERE, C. Les rites profanes. Paris: Presses Universitaires de France, 1995.

RULFO, J. El gallo de oro. Madrid: Alianza Era, 1980.

SEITENFUS, W. Combate. Carazinho: Ziramar, 1975.

SERVICE, E. R. Profiles in ethnology. New York: Harper \& Row, 1963.

TEIXEIRA, S. A. Os recados das festas: representações e poder no Brasil. Rio de Janeiro: Funarte: Instituto Nacional do Folclore, 1988.

THOMAS, K. O homem e o mundo natural. São Paulo: Companhia da Letras, 1989.

TURNER, V. O processo ritual. Petrópolis: Vozes, 1974.

TURNER, V. La selva de los símbolos. Madrid: Siglo XXI, 1980.

VARGAS, A. D. El gallo de combate. México: Diana, 1986. 